\title{
Evaluation of Sustainable Supply Chain Risk: evidence from the Iranian food industry
}

\begin{abstract}
The food industry is directly related to the health of humans, society but little attention has been paid to the assessment of sustainable supply chain risk management in this area. This study aims to develop a framework for assessing the sustainable supply chain risk management in the realm of food industry (confectionery and chocolate) with case studies of three generic companies denotes as A1, A2 and A3. The proposed risk management was evaluated by three producers' companies of Iran. These three companies were ranked by the Fuzzy weighted aggregated sum product assessment (F-WASPAS) method in Excel. The evaluation was carried out using integrated multi-criteria decision-making methods BWMWASPAS. Via an extensive literature review in the area of sustainable supply chain, sustainable food supply chain and risks in this, nine risk criteria and 59 sub-criteria of risk were identified. Using expert opinion in the food industry, eight risk criteria and 39 risk subcriteria were identified for final evaluation. The final weight of the main and sub-criteria was obtained using the FUZZY Best-Worst Method (F-BWM) method via LINGO 17 software. Risk management in the sustainable supply chain has the role of identifying, analyzing and providing solutions to control risks. The following criteria in each group gained more weight: loss of credibility and brand, dangerous and unhealthy working environment, unproductive use of energy, human error, supplier quality, quality risk, product perishability, and security. Among the criteria, the economic risks have the highest weight and among the alternatives, A3 has obtained first ranking. In terms of sub-criteria analysis, loss of credibility and brand, dangerous and unhealthy working environment, unproductive use of energy, human error, supplier quality, quality risk, product perishability, security are ranked first amongst other sub-criteria on each respected risk.
\end{abstract}

Keywords: Sustainable Supply Chain, Fuzzy Best-Worst Method, Fuzzy WASPAS Method, Food Industry, Sustainable Food Chain, Risk Management

\section{Introduction}

Today, supply chain managers attempt to maximize profits and minimize their costs, due to increased concerns about reducing raw materials, increasing waste, increasing pollutants, spreading pollution, and given that failure to observe ethical issues and responsibilities will increase costs. They seek to reduce adversarial environmental impacts and to increase social satisfaction. Organizations are at a critical and complex phase, which must operate in a complex and dynamic environment to overcome the challenges (Darestani and Shamami, 2019).

Negative social and environmental impacts are generated by the rapid population growth. Since consumerism and demand are increasing from ecosystem services, thus organizations must move towards sustainability. As well as raising the awareness of stakeholders, customers and the government about environmental issues, organizations are forced to integrate sustainability with their supply chain management (Fritz, 2019).

Sustainability includes environmental, social and economic. Organizations expand globally to reduce their costs. As a result, they will face uncertainties. If an organization is only looking for efficiency and risks that may be faced at a global level as well as ignore risk management, it will be doomed to fail. Thus, evaluating risk management for organizations is importance (Cervantes-Cabrera and Briano-Turrent, 2018).

The management of supply chain risks has emerged as an important area of study in the field of supply chain management. Companies and practitioners pay considerable attention to risk management due to the growing frequency of risk events and their effect on companies. Risk 
modeling of the supply chain is an important subject that requires further study (Aqlan and Lam, 2015). Therefore, the need to collaboratively approach risk management has been increasingly emphasized in recent literature ( $\mathrm{Li}$ et $a l ., 2015)$ and a key to achieving this objective is to promote the integration of the supply chain (Munir et al, 2020).

This article includes five sections. The first part introduces the problem at hand, the second part deals with a review of the state of the art, which comprises of the management of sustainable supply chain risk and studies on this subject, the research framework and the criteria examined in this study. The third part deals with the research methods and ultimately is provides conclusions and implications.

\section{Literature Review}

Nowadays, business environment is much more competitive due to the risks, instability and uncertainty. As a result, organizations must be able to cope with these challenges, and this has led to the emergence of risk management rules in the last decade (Nikookar Nooshabadi, 2014). In addition, researchers have attempted to prevent failure as one of the main measures to improve continuous quality (Mirzaei and Darestani, 2016). Making decisions about the most important risk play a necessary role at industry (Mirzaei et al., 2014). In general, the risk management process consists of two parts: risk assessment and risk response (Lee et al., 2009). Many companies expand their supply chain to a global level to reduce costs and that can lead to possible new risks (Ellis et al., 2011). These companies will fail by ignoring risk management and just looking for high efficiency (Dong and Cooper, 2016; Fan et al., 2016). Sustainable supply chain is one that addresses environmental and social issues alongside its economic performance in order to sustain itself (Ghasemi et al., 2015). Recently, environmental and social considerations have been considered by organizations. Since supply chain managers seek to maximize profit, minimize operating cost, reduce negative environmental impacts, and increase social satisfaction, as well as sustainability thinking in business due to increased quality (Mangla et al., 2015; Seuring and Muller, 2008). Sustainable supply chain is difficult and sometimes impossible to achieve due to the increase of interactions between the modern supply chain and the increase of communications. Factors such as: political issues, demand fluctuations, global financial crisis, technological substitution, natural disasters, are the dangers that make supply chain managers losing their readiness when they enter these developments (Rostamzadeh et al., 2018). In this regard, sustainable strategies should consider the extent of future uncertainty and decisions that can create risks for the natural and social environment (Giannaakis and Papadopoulos, 2016).

Risk management in supply chains is one of the main issues in recent research. The uncertainty in the global economy, what has led to the development of a complex supply chain is the business process (Giannakis and Papadopoulos, 2016).

The supply chain risk is any risk from the supplier's point of view until delivery of the final product. Concerns about the environment in the sustainable supply chain include reducing energy consumption, recycling, landfill. Also, social concerns include wages, ethics, work behavior, sexual justice and relationships at work (Christopher and lee, 2004). Organizational sustainability occurs when an organization maintains its social and environmental responsibility while maintaining its financial sustainability. It has at least a negative impact on the environment and stops activities that will be cause damage to it (Rostamzadeh et al., 2018).

Risk identification is the first step that identifies all the risks of a sustainable supply chain which are identified using checklist and classification, and so on. The second step is to assess all the risks identified in the previous step. In the third step, the risks are analyzed and prioritized by various tools (Giannakis and Papadopoulos,2015). 
Yakovleva et al. (2010) examined the application of the LCA and its relationship to the food industry, combining it with economic tools, designing environmentally friendly products, methods for tracking, and finally managing environmental issues in the food industry (Yakovleva et al., 2010). Ahi and Searcy (2011) analyzed the definitions of green supply chain management and sustainable supply chain management and proposed two sets: 1 . sustainable supply chain management as social, environmental, economic, flexible and longterm focus, and 2. supply chain management as flow, coordination, shareholders, value, efficiency and focus of performance (Ahi and Searcy, 2013). Seuring (2013) investigated modeling approaches for sustainable supply chain management. He stated that the sustainable social dimension was not considered and believed that little empirical research was carried out (Seuring, 2013). Gold et al. (2013) stated that sustainability issues could help multinational companies in the BoP, and that further research was required (Gold et al., 2013). Gualandris and Kalchschmidt (2014) concluded that customer pressure and innovation had a positive impact on internal operations (sustainable process management) (Gualandris and Kalchschmidt, 2014).

Ghasemi et al. (2015) identified and prioritized indices that contributed to the stability of food supply chain. Using the ANP method and the super decision software, they concluded that indicators of productivity and market concentration, water consumption, energy consumption, waste recycling, transportation, employment volume, employment quality and employment balance are of the highest importance as well as the economic dimension has a higher weight than social and environmental dimension (Ghasemi et al., 2015). Badri Ahmadi et al. (2017) investigated the assessment of the social sustainability of the supply chain using the BWM method. They believed that has been paid less attention to the sustainable social dimension in comparison with the environmental and economic dimensions and stated that the social dimension can have a significant impact on sustainable supply chains and provided a framework for assessing social sustainability (Badri Ahmadi et al., 2017). Wan Ahmad et al. (2017) examined the impact of external forces on the sustainability of the oil and gas supply chain using the BWM method. They concluded that economic and political stability is more important than other factors and energy transmission is of the least importance (Wan Ahmad et al., 2017). Qorri et al. (2018) analyzed measurement methods to assess the sustainable performance of supply chains and provided a new conceptual framework (Qorri et al., 2018). Muhammad et al. (2018) examined the sustainability management and risk management in the fashion supply chain and their purpose was to examine the relationship between these two important issues have used the Context intervention mechanisms outcome (CIMO) criterion for analysis. Their research has shown that research on this issue is relatively incomplete (Muhammad et al., 2018). Gokarn and Kuthambalayan (2019) after reviewing the management of uncertainty in the sustainable supply chain of fresh produce concluded that organizations should balance the benefits and investment in resources to manage uncertainty (Gokarn and S. Kuthambalayan, 2019). Bastas and Liyanage (2019) to improve organizational sustainability, they examined the integration of quality management and supply chain management. They used the principles of supply chain management and quality management for sustainability development and they presented a way design and a diagnostic tool to integrate these two issues (Bastas and Liyanage, 2019).

Wu and Pagell (2011) concluded that the development of a unique supply chain requires a set of decisions. Although sustainable supply chain management has three dimensions: economic, social, and environmental, but the focus of this research was on environmental issues only (Wu and Pagell, 2011). Mangla et al. (2015) examined the operational risk, supply risk, product risk, financial risk, demand risk, government and institutional risk, and 
their goal was to analyze the risk in the green supply chain using the FAHP method (Mangla et al., 2015). Aqlan and Lam (2015) provided an integrated framework for assessing supply chain risk. It also addressed the risks of supply, customer risks, process and control risks, technology risks, product risks, and cultural risks with the aim of establishing a fuzzy-based hybrid framework for assessing supply chain risk using survey, Bow-Tie analysis, and fuzzy inference system (FIS) (Aqlan and Lam, 2015). Cooper and Dong (2016) developed a supply chain risk assessment model based on an Order-Of-Magnitude Analytical Hierarchy Process (OM-AHP) to compare tangible and invisible quantities that affect supply chain risks. They explained that the supply chain risk assessment framework includes three steps: risk identification, risk assessment and ranking and risk analysis. For the effectiveness of the risk assessment, they presented and tested the results in a two-way risk matrix based on the probability and severity of the outcome (Cooper and Dong, 2016). Wiengarten et al. (2016) investigated the integration of supply chain, rule of law, risk management, operational performance, and communication perspective with the aim of discovering the role of risk and risk management practices in the success of supply chain integration in terms of their impact on cost performance and innovation through International Manufacturing Strategy Survey (IMSS) (Wiengarten et al., 2016). Su et al. (2016) examined sustainable design, communities for sustainability, operational sustainable control, sustainable certificates and growth (Su et al., 2016). Giannakis and Papadopoulos (2016) identified 30 risks among the three pillars of sustainability (environmental, social and economic) and used the content analysis and Failure Modes and Effects Analysis (FMEA) methods to evaluate and analyze them. The results of Song et al (2017) showed that the lack of proper supplier selection is the most important risk factor for SSCM. Because supplier selection plays an important role in achieving social, environmental and economic benefits (Song et al., 2017). Valinejad and Rahman (2018) provided a framework for Sustainable Supply Chain Management (SSCM) of telecom companies and some of these companies have been analyzed using the FMEA method. Based on the capacity of each industry, they proposed solutions to eliminate any risk and after identifying the causes and consequences of each risk, it was concluded that $66 \%$ of the risks are related to the technical component and $53 \%$ are related to the suppliers (Valinejad and Rahmani, 2018). Sreedevi and Saranga (2017) examined the relationships between the uncertainty of the environment and the supply chain risks and the impact of the variable supply chain flexibility by International Manufacturing Strategy Survey (IMSS) and Structural Equation Modeling (Sreedevi and Saranga, 2017). Rostamzadeh et al. (2018) reviewed the assessment of sustainable supply chain risk management. They considered seven major criteria and 44 sub-criteria and after prioritizing the criteria, they chose the best company among the four companies. They used the Technique in order of preference by similarity to ideal solution (TOPSIS)- Criteria importance through inter-criteria correlation (CRITIC) method in a fuzzy environment. They believed that industries need globalization to increase their profits, including risks and uncertainties. Sustainable supply chain management failures in most cases when faced with risks and need to assess the risk management of sustainable supply chains (Roatamzadeh et al., 2017). Ghadimi et al. (2019) modeled and analyzed the sustainable supply chain. They concluded that in recent years the preservation of economic, social and environmental foundations has increased in Resources, Conservation and Recycling (RCR) publications (Ghadimi et al., 2019). The summary of some researches about supply chain risks are represented at Table 1. 
Table 1. Summary of some researches about supply chain risk

\begin{tabular}{|c|c|c|c|c|}
\hline Author & Aims & Method & Risks & Results \\
\hline $\begin{array}{c}\text { Wu and } \\
\text { Pagell (2011) }\end{array}$ & $\begin{array}{l}\text { Balancing priorities: } \\
\text { Decision-making in } \\
\text { sustainable supply } \\
\text { chain management }\end{array}$ & $\begin{array}{l}\text { Grounded } \\
\text { theory } \\
\text { building } \\
\text { approach }\end{array}$ & Environmental risk & $\begin{array}{l}\text { The development of } \\
\text { a unique supply } \\
\text { chain requires a set } \\
\text { of decisions }\end{array}$ \\
\hline $\begin{array}{c}\text { Ahi and } \\
\text { Searcy }(2011)\end{array}$ & $\begin{array}{l}\text { Analyzing the } \\
\text { definitions of green } \\
\text { supply chain } \\
\text { management and } \\
\text { sustainable supply } \\
\text { chain management }\end{array}$ & & $\begin{array}{l}\text { Social, environmental, } \\
\text { economic, flexible and } \\
\text { long-term focus }\end{array}$ & \\
\hline $\begin{array}{l}\text { Mangla et al. } \\
\quad(2015)\end{array}$ & $\begin{array}{l}\text { Analyzing the risk in } \\
\text { the green supply } \\
\text { chain using the } \\
\text { FAHP method }\end{array}$ & $\begin{array}{l}\text { FAHP } \\
\text { method }\end{array}$ & $\begin{array}{l}\text { The operational risk, } \\
\text { supply risk, product risk, } \\
\text { financial risk, demand } \\
\text { risk, government and } \\
\text { institutional risk }\end{array}$ & $\begin{array}{l}\text { Operational } \\
\text { category risks are } \\
\text { the most important } \\
\text { risks in green } \\
\text { supply chain. }\end{array}$ \\
\hline $\begin{array}{l}\text { Aqlan and } \\
\text { Lam (2015) }\end{array}$ & $\begin{array}{l}\text { Establishing a fuzzy- } \\
\text { based hybrid } \\
\text { framework for } \\
\text { assessing supply } \\
\text { chain risk using } \\
\text { survey, Bow-Tie } \\
\text { analysis, and FIS }\end{array}$ & $\begin{array}{l}\text { Fuzzy-based } \\
\text { hybrid, } \\
\text { Bow-Tie } \\
\text { analysis, } \\
\text { and FIS }\end{array}$ & $\begin{array}{l}\text { Risks of supply, customer } \\
\text { risks, process and control } \\
\text { risks, technology risks, } \\
\text { product risks, and cultural } \\
\text { risks }\end{array}$ & $\begin{array}{l}\text { Numerical results } \\
\text { for the company } \\
\text { considered in this } \\
\text { study showed that } \\
\text { the risk scores for } \\
\text { the two main } \\
\text { product categories } \\
\text { are } 22 \% \text { and } 19 \% \text {, } \\
\text { respectively. }\end{array}$ \\
\hline $\begin{array}{l}\text { Cooper and } \\
\text { Dong }(2016)\end{array}$ & $\begin{array}{c}\text { Developing a supply } \\
\text { chain risk } \\
\text { assessment model } \\
\text { based on an OM- } \\
\text { AHP to compare } \\
\text { tangible and } \\
\text { invisible quantities } \\
\text { that affect supply } \\
\text { chain risks }\end{array}$ & OM-AHP & $\begin{array}{l}\text { Lack of skilled workers, } \\
\text { Wage increases, } \\
\text { Technology upgrades, } \\
\text { Supply interruptions, } \\
\text { Machine breakdowns, } \\
\text { Order fluctuation, Urgent } \\
\text { orders, Exchange rate } \\
\text { fluctuation, Low supplier } \\
\text { integration, Inaccurate } \\
\text { shipment from Suppliers, } \\
\text { Inaccurate shipment to } \\
\text { customers, Raw parts } \\
\text { scarcity, Transportation } \\
\text { bottlenecks, Market } \\
\text { requirements } \\
\text { Transformation, Vendor } \\
\text { lock, Hurricane, Low } \\
\text { supplier transparency, } \\
\text { Information distortion, } \\
\text { Security of information } \\
\text { sharing, Broken contract, } \\
\text { Supplier bankruptcy, } \\
\text { Products damaged in } \\
\text { transits, Customer } \\
\text { defection, Political policy, } \\
\text { Earthquake, War, } \\
\text { Warranty policy, } \\
\text { Terrorism, Financial } \\
\text { Crisis, Transport } \\
\text { provider's Fragmentation, } \\
\text { Inaccurate demand } \\
\text { forecasts }\end{array}$ & $\begin{array}{c}\text { The critical risks } \\
\text { are: } \\
\text { lack of skilled } \\
\text { workers, wage } \\
\text { increases, } \\
\text { technology } \\
\text { upgrades, and } \\
\text { supply } \\
\text { interruptions. } \\
\text { machine } \\
\text { breakdowns, order } \\
\text { fluctuation, urgent } \\
\text { orders, exchange } \\
\text { rate } \\
\text { fluctuation, low } \\
\text { supplier integration, } \\
\text { inaccurate shipment } \\
\text { from suppliers, } \\
\text { inaccurate shipment } \\
\text { to customers, and } \\
\text { raw parts scarcity } \\
\text { are high risk. }\end{array}$ \\
\hline
\end{tabular}




\begin{tabular}{|c|c|c|c|c|}
\hline $\begin{array}{l}\text { Wiengarten } \\
\text { et al. }(2016)\end{array}$ & $\begin{array}{l}\text { Exploring the role of } \\
\text { risk and risk } \\
\text { management } \\
\text { practices in the } \\
\text { success of supply } \\
\text { chain integration in } \\
\text { terms of their impact } \\
\text { on cost and } \\
\text { innovation } \\
\text { performance }\end{array}$ & $\begin{array}{c}\text { OLS } \\
\text { analysis }\end{array}$ & Risk management & $\begin{array}{l}\text { Companies can } \\
\text { complement and } \\
\text { strengthen the } \\
\text { performance impact } \\
\text { of their supplier } \\
\text { integration practices } \\
\text { through supply } \\
\text { chain risk } \\
\text { management } \\
\text { practices in risky } \\
\text { environments }\end{array}$ \\
\hline $\begin{array}{c}\text { Giannakis } \\
\text { and } \\
\text { Papadopoulos } \\
(2016)\end{array}$ & $\begin{array}{l}\text { Exploring the nature } \\
\text { of sustainability- } \\
\text { related supply chain } \\
\text { risks }\end{array}$ & FMEA & $\begin{array}{l}\text { Environmental, social and } \\
\text { economic }\end{array}$ & $\begin{array}{l}\text { Endogenous } \\
\text { environmental risks } \\
\text { are perceived to be } \\
\text { the most important } \\
\text { across different } \\
\text { industries and the } \\
\text { interconnectedness } \\
\text { between several } \\
\text { sustainability- } \\
\text { related risks is very } \\
\text { high }\end{array}$ \\
\hline $\begin{array}{l}\text { Song et al. } \\
\quad(2017)\end{array}$ & $\begin{array}{l}\text { Identifying critical } \\
\text { risk factors of } \\
\text { sustainable supply } \\
\text { chain management }\end{array}$ & DEMATEL & $\begin{array}{l}\text { Environmental, Social, } \\
\text { Financial/economic }\end{array}$ & $\begin{array}{l}\text { Failure to select the } \\
\text { right suppliers is the } \\
\text { most prominent risk } \\
\text { factor for SSCM }\end{array}$ \\
\hline $\begin{array}{c}\text { Valinejad } \\
\text { and Rahman } \\
\qquad(2018)\end{array}$ & $\begin{array}{l}\text { A comprehensive } \\
\text { and credible } \\
\text { framework is } \\
\text { proposed } 11 \\
\text { for managing the } \\
\text { sustainability risks } \\
\text { of the supply chain } \\
\text { for } \\
\text { telecommunications } \\
\text { companies, }\end{array}$ & $\begin{array}{l}\text { FMEA } \\
\text { method }\end{array}$ & $\begin{array}{c}\text { Environment, Social, } \\
\text { Economic, Institutional, } \\
\text { Technical }\end{array}$ & $\begin{array}{l}66 \% \text { of the risks are } \\
\text { related to the } \\
\text { technical } \\
\text { component and } 53 \% \\
\text { are related to the } \\
\text { suppliers }\end{array}$ \\
\hline $\begin{array}{l}\text { Rostamzadeh } \\
\text { et al. }(2018)\end{array}$ & $\begin{array}{l}\text { The assessment of } \\
\text { sustainable supply } \\
\text { chain risk } \\
\text { management }\end{array}$ & $\begin{array}{l}\text { TOPSIS - } \\
\text { CRITIC } \\
\text { method in a } \\
\text { fuzzy } \\
\text { environment }\end{array}$ & $\begin{array}{c}\text { Environmental } \\
\text { Risks, Organizational } \\
\text { Risks, Sustainable } \\
\text { Supply risks, Sustainable } \\
\text { Production } \\
\text { risks/manufacturer, } \\
\text { Sustainable } \\
\text { Distribution risks, } \\
\text { Sustainable } \\
\text { Recycling risks, IT related } \\
\text { risks }\end{array}$ & $\begin{array}{l}\text { Sustainable supply } \\
\text { chain management } \\
\text { failures in most } \\
\text { cases when faced } \\
\text { with risks and need } \\
\text { to assess the risk } \\
\text { management of } \\
\text { sustainable supply } \\
\text { chains }\end{array}$ \\
\hline $\begin{array}{l}\text { Ghadimi et } \\
\text { al. (2019) }\end{array}$ & $\begin{array}{l}\text { Analyzing the } \\
\text { sustainable supply } \\
\text { chain }\end{array}$ & Review & $\begin{array}{l}\text { Economic, social and } \\
\text { environmental }\end{array}$ & $\begin{array}{l}\text { The preservation of } \\
\text { economic, social } \\
\text { and environmental } \\
\text { foundations has } \\
\text { increased in RCR } \\
\text { publications }\end{array}$ \\
\hline $\begin{array}{l}\text { Wasim Syed } \\
\text { et al. }(2019)\end{array}$ & $\begin{array}{c}\text { An Empirical } \\
\text { Examination of } \\
\text { Sustainable Supply } \\
\text { Chain Risk and } \\
\text { Integration Practices }\end{array}$ & $\begin{array}{l}\text { the } \\
\text { exploratory } \\
\text { factor } \\
\text { analysis } \\
\text { (EFA) }\end{array}$ & $\begin{array}{l}\text { Internal business process } \\
\text { risks, sustainable supply } \\
\text { risks, and sustainable } \\
\text { demand risks }\end{array}$ & $\begin{array}{c}\text { Sustainable } \\
\text { internal business } \\
\text { process risks, } \\
\text { sustainable supply } \\
\text { risks, and } \\
\text { sustainable demand }\end{array}$ \\
\hline
\end{tabular}




\begin{tabular}{|c|c|c|c|c|}
\hline & & & & $\begin{array}{l}\text { risks have a } \\
\text { negative } \\
\text { relationship with } \\
\text { supply chain } \\
\text { integration }\end{array}$ \\
\hline $\begin{array}{c}\text { Mhelembe } e t \\
\text { al. (2019) }\end{array}$ & $\begin{array}{l}\text { The relationship } \\
\text { between supply } \\
\text { chain risks, } \\
\text { flexibility and } \\
\text { performance in the } \\
\text { South African public } \\
\text { sector }\end{array}$ & $\begin{array}{l}\text { A structural } \\
\text { equation } \\
\text { modelling } \\
\text { procedure }\end{array}$ & $\begin{array}{l}\text { Government policies, } \\
\text { supply complexity, } \\
\text { availability of skills, } \\
\text { supplier performance } \\
\text { monitoring, information } \\
\text { security and process } \\
\text { efficiency exert } \\
\text { significant influences } \\
\text { factors }\end{array}$ & $\begin{array}{l}\text { Six supply chain } \\
\text { risk on supply chain } \\
\text { flexibility. In turn, } \\
\text { supply chain } \\
\text { flexibility exerts a } \\
\text { positive influence } \\
\text { on the performance } \\
\text { of the public supply } \\
\text { chain. }\end{array}$ \\
\hline $\begin{array}{l}\text { Ghadge } e t \text { al. } \\
\qquad(2020)\end{array}$ & $\begin{array}{c}\text { Analyzing the } \\
\text { manufacturer- } \\
\text { supplier relational } \\
\text { perspective under } \\
\text { the influence of } \\
\text { exogenous financial } \\
\text { risk. }\end{array}$ & $\begin{array}{c}\text { VIKOR and } \\
\text { NSGA III } \\
\text { methods }\end{array}$ & Financial risk & $\begin{array}{c}\text { Financial risk } \\
\text { impact not only the } \\
\text { profits, but also } \\
\text { affect the long-term } \\
\text { relationship } \\
\text { between supply } \\
\text { chain stakeholders. }\end{array}$ \\
\hline $\begin{array}{l}\text { Current } \\
\text { study }\end{array}$ & $\begin{array}{l}\text { to develop a } \\
\text { framework for } \\
\text { assessing the } \\
\text { sustainable supply } \\
\text { chain risk } \\
\text { management in the } \\
\text { realm of food } \\
\text { industry }\end{array}$ & $\begin{array}{c}\text { F-WASPAS } \\
\text { and F- } \\
\text { BWM }\end{array}$ & $\begin{array}{c}\text { Economic risks, Social } \\
\text { Risks, Environmental } \\
\text { risks, Organizational } \\
\text { Risks, Supply risks, } \\
\text { Production Risks, } \\
\text { Distribution risks, } \\
\text { Information technology } \\
\text { risks }\end{array}$ & $\begin{array}{l}\text { Criteria in each } \\
\text { group gained more } \\
\text { weight: loss of } \\
\text { credibility and } \\
\text { brand, dangerous } \\
\text { and unhealthy } \\
\text { working } \\
\text { environment, } \\
\text { unproductive use of } \\
\text { energy, human } \\
\text { error, supplier } \\
\text { quality, quality risk, } \\
\text { product } \\
\text { perishability, and } \\
\text { security. Among the } \\
\text { criteria, the } \\
\text { economic risks have } \\
\text { the highest weight. }\end{array}$ \\
\hline
\end{tabular}

\section{Research Methodology}

3-1 study framework and Case study

First, the main and sub criteria were determined after examining the previous state of the art. By completing the questionnaire by the experts in this area, the main and sub criteria were filtered using the Content validity ratio (CVR) method. A F-BWM questionnaire was prepared to select the best and worst criteria and after paired comparison by experts and integrating them by geometric mean, the main and sub-criteria were weighted by the FBWM method. Then the consistency ratio was calculated and after ensuring consistency, the final weight of the sub-criteria was obtained. In the next step, a decision matrix was created and completed by the expert of each company and ranked after the normalization with the F-WASPAS method. Finally, the conclusions of these calculations are presented (Figure 1). The assumptions made throughout this research are:

1) The main and sub criteria are independent.

2) The experts' opinions would carry the same weight. 


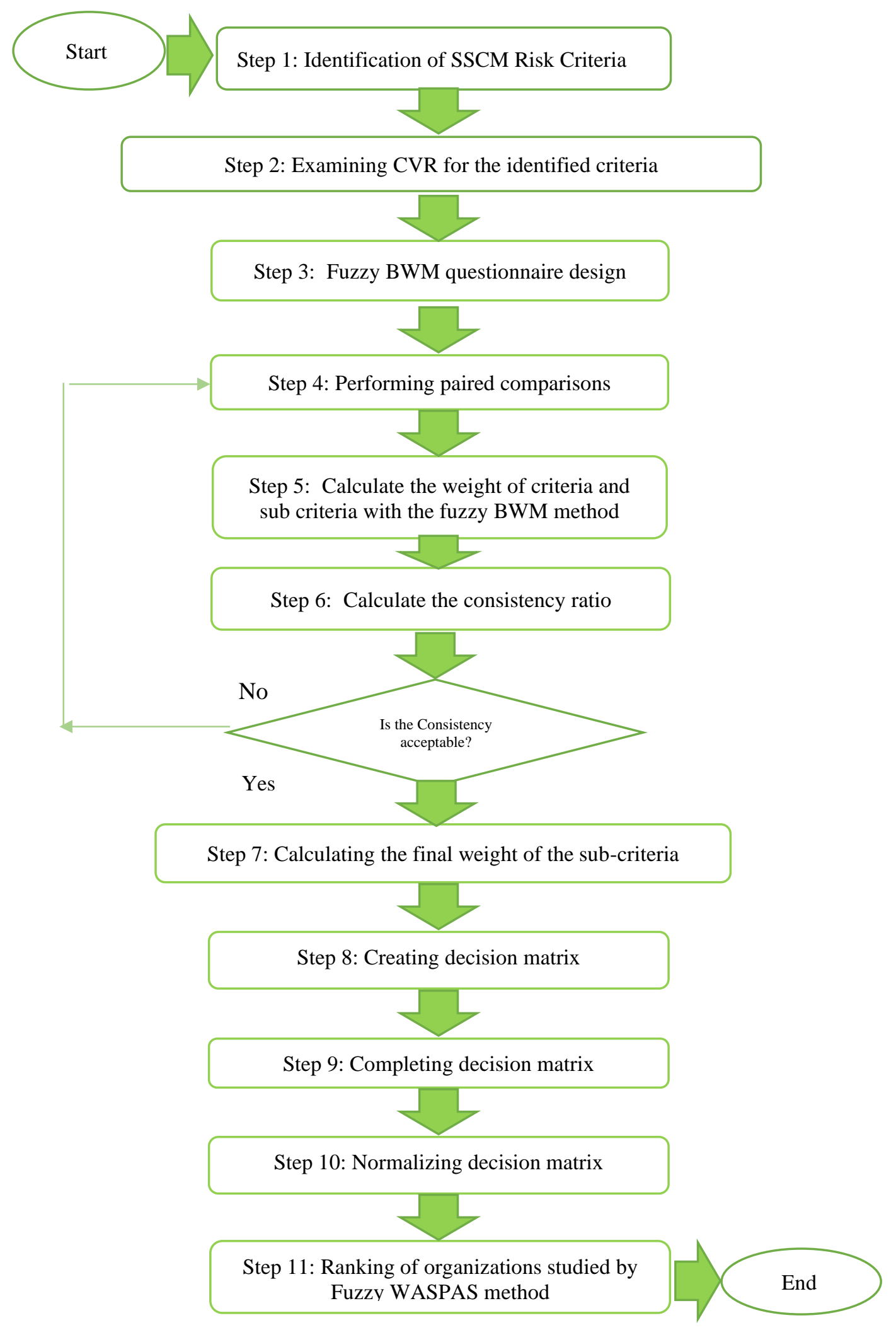

Figure 1. Research framework

In this research, three production plant in the field of food industry (confectionery and chocolates) have been investigated from Karaj Province of Iran as shown by red flag in 
Figure 2. The first company subjected to this study namely A1 unit is located in Karaj $10^{\text {th }}$ $\mathrm{km}$ Chalous road (manufacturer of cookie), A2 production unit in Karaj, KamalShahr, Baharestan industrial city (manufacturer of Biscuit), A3 production unit located in Karaj, KemalShahr, Baharestan industrial city (manufacturer of chocolates).

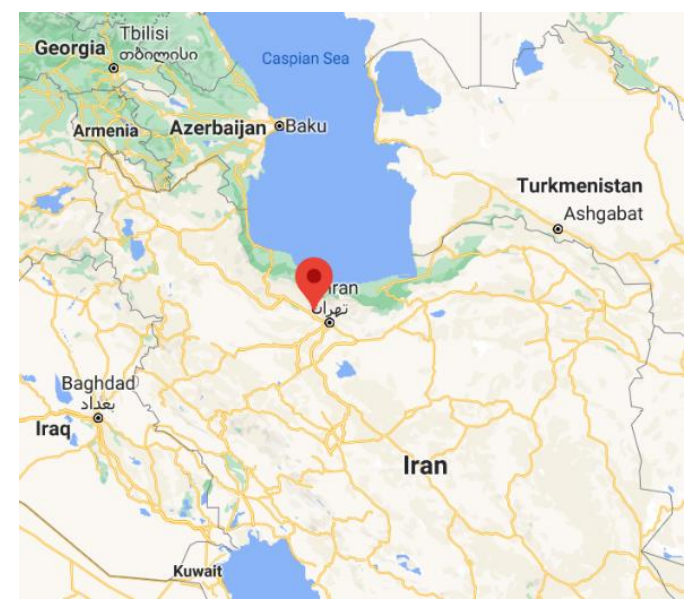

Figure 2. Location of case studies (Karaj Province, Iran)

Step 1) After reviewing the state of the art and the main and sub-criteria for the sustainable risks that exist in the supply chain as well as in the supply chain of the food industry. Nine criteria and 59 sub criteria are identified using the views of the faculty members of universities and experts according to Table 2.

A questionnaire was prepared to select the necessary criteria and sub-criteria in the food industry and given to nine experts. The number of experts should not be high, with a range of 5 to 15 individuals suggested (Vazifehdan and Darestani, 2019). They were asked to give their opinions and suggestions for other criteria as well.

\section{Expert qualification}

The criteria used for selecting experts are as follows:

(a) their dominance on all units and departments of the supply chain of the food industry, such as a production manager, a quality manager and a laboratory manager.

b) having at least 10 years of working experience in the food industry.

c) minimum degree level in management or engineering fields.

Table 2. Identification of the criteria and sub-criteria of SSCRM

\begin{tabular}{|c|c|c|}
\hline Risk criteria & Risk sub-criteria & References \\
\hline \multirow{6}{*}{ Economic Risk } & Price fluctuations and organization costs & (Wenyan et al., 2017; Alam Tabriz et al., 2017) \\
\hline & Inflation & $\begin{array}{c}\text { (Tummala and Schoenherr, 2011; Wenyan et } \\
\text { al., 2017; Alam Tabriz et al., 2017) }\end{array}$ \\
\hline & Declining market share & $\begin{array}{c}\text { (Afgan and Caravalho, 2004; Alam Tabriz et } \\
\text { al., 2017) }\end{array}$ \\
\hline & Loss of credibility and brand & $\begin{array}{l}\text { (Sodhi and Tang, 2009; Alam Tabriz et al., } \\
\text { 2017) }\end{array}$ \\
\hline & Boycotts & $\begin{array}{c}\text { (Giannakis and Papadopoulos, 2015; Mihalis } \\
\text { and Thanos, 2016) }\end{array}$ \\
\hline & Financial crisis & $\begin{array}{c}\text { (Giannakis and Papadopoulos, 2015; Mihalis } \\
\text { and Thanos, 2016) }\end{array}$ \\
\hline Social Risk & $\begin{array}{l}\text { Dangerous and unhealthy working } \\
\text { environment }\end{array}$ & $\begin{array}{c}\text { (Giannakis and Papadopoulos, 2015; Alam } \\
\text { Tabriz et al., 2017) }\end{array}$ \\
\hline
\end{tabular}


Human rights violations

Violation of ethics in business

Social instability / unrest

Ageing population and demographic challenges

(Giannakis and Papadopoulos, 2015)
(Christopher and Lee, 2004; Giannakis and Papadopoulos, 2015; Ghasemi et al., 2015; Alam Tabriz et al., 2017)

(Alam Tabriz et al., 2017)

(Christopher and Lee, 2004; Alam Tabriz et al., 2017) Tabriz et al., 2017)
Unfair wages

Hiring policies (such as contract, insurance)
(Christopher and Lee, 2004; Giannakis and Papadopoulos, 2015)

(Ghasemi et al., 2015; Giannakis and Papadopoulos, 2015)

(Christopher and Lee, 2004)
Natural events

Inefficient use of resources

Environmental pollution

Hazardous waste generation

(transportation, greenhouse gas emissions, product waste and excessive or unnecessary packaging)

\section{Environmental} Risk
Non-compliance with sustainability laws

(Bribery, labor law, tax evasion and ...)
(Alam Tabriz, 2017)

(Alam Tabriz et al., 2017)

(Christopher and Lee, 2004; Giannakis and

Papadopoulos, 2015; Alam Tabriz et al., 2017; Mukhta et al., 2019;)

(Ghasemi et al., 2015; Alam Tabriz et al., 2017)

(Giannakis and Papadopoulos, 2015; Alam Tabriz et al., 2017)
Wars and terrorisms

Fires and explosions

Unproductive use of energy
(Rostamzadeh et al., 2018; Khan et al., 2018)

(Giannakis and Papadopoulos, 2015)
(Christopher and Lee, 2004; Giannakis and Papadopoulos, 2015; Ghasemi et al., 2015)
Patent infringements

Government policy
(Giannakis and Papadopoulos, 2015)

(Mhelembe and Mafini., 2019., Rostamzadeh et al., 2018)
(Rostamzadeh et al., 2018)

Poor interrelationships between supply chain partners (lack of knowledge about sustainable technology, operations and practices between partners)

(Jayaram et al., 2010., Rostamzadeh et al., 2018)

risk (Wasim Syed et al., 2019
Sustainable Supply risks
Lack of commitment in the green supply chain

Management policy failures

Capacity constraints
(Rostamzadeh et al., 2018)

(Ortegoli and Kabaranzad Ghadim, 2016. Rostamzadeh et al., 2018)

(Shafiq et al., 2017; Rostamzadeh et al., 2018; Wasim Syed et al., 2019;) 


\begin{tabular}{|c|c|c|}
\hline \multirow[t]{7}{*}{$\begin{array}{l}\text { (Wasim Syed } \\
\text { et al., 2019) }\end{array}$} & Key supplier failures & $\begin{array}{l}\text { (Gouda and Saranga., 2018; Rostamzadeh et } \\
\text { al., 2018) }\end{array}$ \\
\hline & Supplier quality & (Rostamzadeh et al., 2018) \\
\hline & $\begin{array}{l}\text { Supplier uncertainty and lack of suitable } \\
\text { supplier selection }\end{array}$ & (Rostamzadeh et al., 2018) \\
\hline & Material order risks & (Rostamzadeh et al., 2018) \\
\hline & Inventory risks & $\begin{array}{l}\text { (Rostamzadeh et al., 2018; Wasim Syed et al., } \\
\text { 2019) }\end{array}$ \\
\hline & $\begin{array}{l}\text { Limited number of selecting green } \\
\text { suppliers }\end{array}$ & $\begin{array}{l}\text { (Rostamzadeh et al., 2018; Wasim Syed et al., } \\
\text { 2019) }\end{array}$ \\
\hline & Supplier's financial instability & $\begin{array}{l}\text { (Rostamzadeh et al., 2018; Ghadge et al., } \\
\text { 2020) }\end{array}$ \\
\hline \multirow{8}{*}{$\begin{array}{l}\text { Sustainable } \\
\text { Production } \\
\text { risks }\end{array}$} & Product design risk & $\begin{array}{l}\text { (Palousis et al., 2010; Schulte and Hallstedt, } \\
\text { 2018; Rostamzadeh } \text { et al., 2018) }\end{array}$ \\
\hline & Risk of production capacity & (Rostamzadeh et al., 2018; Sun et al., 2020) \\
\hline & Risk in demand & $\begin{array}{c}\text { (Mangla et al., 2015; Rostamzadeh et al., 2018; } \\
\text { Wasim Syed et al., 2019;) }\end{array}$ \\
\hline & Quality risk & (Rostamzadeh et al., 2018; Tse et al., 2019) \\
\hline & Poor planning & (Rostamzadeh et al., 2018) \\
\hline & Forecast errors & $\begin{array}{l}\text { (Rostamzadeh et al., 2018; Wasim Syed et al., } \\
\text { 2019) }\end{array}$ \\
\hline & Strike & (Paul et al., 2016; Rostamzadeh et al., 2018) \\
\hline & Machines \& equipment risks & (Ladisa, 2017; Rostamzadeh et al., 2018) \\
\hline \multirow{5}{*}{$\begin{array}{c}\text { Sustainable } \\
\text { Distribution } \\
\text { risks }\end{array}$} & $\begin{array}{c}\text { Proximity to airports } \\
\text { quality of roads }\end{array}$ & (Rostamzadeh et al., 2018) \\
\hline & Demand fluctuations (supply flexibility) & $\begin{array}{c}\text { (Sreedevi and Saranga, 2017; Rostamzadeh et } \\
\text { al., 2018; Wasim Syed et al., 2019) }\end{array}$ \\
\hline & Demand forecasting risks & $\begin{array}{l}\text { (Seyedan and Mofakheri, 2020; Chen and } \\
\text { Seshadri, 2006; Rostamzadeh et al., 2018) }\end{array}$ \\
\hline & Market related risks & (Rostamzadeh et al., 2018) \\
\hline & Product perishability risk & $\begin{array}{c}\text { (Bogataj et al., 2020; Rostamzadeh et al., } \\
\text { 2018) }\end{array}$ \\
\hline \multirow{5}{*}{$\begin{array}{l}\text { Sustainable } \\
\text { Recycling risks }\end{array}$} & Lack of proper sewage infiltration & (Rostamzadeh et al., 2018) \\
\hline & $\begin{array}{l}\text { Inability in use of other companies } \\
\text { wastes }\end{array}$ & (Rostamzadeh et al., 2018) \\
\hline & Discharging of wastes risks & (Rostamzadeh et al., 2018) \\
\hline & Ground water pollution risks & $\begin{array}{l}\text { (Rostamzadeh et al., 2018; Ouedraogo et al., } \\
\text { 2020) }\end{array}$ \\
\hline & Recycling & (Rostamzadeh et al., 2018) \\
\hline \multirow{3}{*}{$\begin{array}{l}\text { IT related } \\
\text { risks }\end{array}$} & Security & $\begin{array}{c}\text { (Rajesh and Ravi, 2015; Mhelembe and } \\
\text { Mafini., 2019) }\end{array}$ \\
\hline & Fail to access information & (Rostamzadeh et al., 2018) \\
\hline & System Failure & (Rostamzadeh et al., 2018) \\
\hline
\end{tabular}

Step 2) After completing the questionnaire by the experts, the content validity of the questionnaire is reviewed by CVR:

$\mathrm{CVR}=\frac{n_{E^{-}-\frac{N}{2}}}{\frac{N}{2}}$ 
CVR (Sarabi and Darestani, 2020) procedure was used for categorization criteria and reducing attributes. In this case, $n_{E}$ is the number of experts who have responded to the 'necessary' options and $\mathrm{N}$ is the total number of experts. The calculated CVR value is larger than the minimum value of CVR (Lawshe, 1975). Those criteria with CVR values meeting this minimum are finally accepted and selected for study (Vazifehdan and Darestani, 2019).

Step 3) Design a F-BWM questionnaire.

At this step, the questionnaire is designed based on the BWM.

Step 4) Performing paired comparisons.

Paired comparisons are completed by experts.

Step 5) Calculate the weight of criteria and sub criteria.

Weights are calculated using F-BWM method in LINGO software.

Step 6) Calculate the consistency ratio.

Step 7) The final weight of the sub-criteria is calculated, so that the weight of each criterion is multiplied by its sub-criteria.

Step 8) The decision matrix is formed.

Step 9) The decision matrix is completed by the experts.

Step 10) The decision matrix is normalized.

Step 11) In this step, using the F-WASPAS method, the options including the organizations studied will be ranked in EXCEL.

\section{3-2 Fuzzy BWM}

In Multiple Criteria Decision-Making (MCDM) methods, a few alternatives are evaluated based on several criteria to select the best alternative. The (weighted) geometric mean method (WGMM) is employed for each entry of the comparison matrices to obtain the group judgment (Ossadnik et al., 2016). In this method, a formula is also used to calculate the consistency ratio in order to verify the validity of the comparisons. Among the prominent features of this method, compared to other MCDM methods, is that it requires fewer comparative data, and this leads to a more powerful comparison, meaning it could provide more reliable answers.

The F-BWM method was first introduced by Guo and Zhao (2017). Its algorithm resembles the best-worst definitive method. The use of fuzzy numbers due to verbal ambiguity of respondents results in greater accuracy and better results in calculations. The process steps for the F-BWM are as follows (Guo and Zhao, 2017):

1) Initially, a set of decision criteria should be determined. For example, in order to buy a car, decision criteria can be of quality $\left(c_{1}\right)$, price $\left(c_{2}\right)$, convenience $\left(c_{3}\right)$, security $\left(c_{4}\right)$, and style $\left(\mathrm{c}_{5}\right)$.

2) In the second step, the best (Absolutely important and very important) criterion and the worst (Weakly important) criterion should be determined by the decision maker and no comparison is made at this step. For example, for a decision maker (buyer of a car), the price may be the absolutely important and the style, the weakly important criterion.

3) At this step, using a number between 1 and 9 set as priorities, the best (most important) criterion should be determined on all other criteria, as follows:

$$
\tilde{A}_{B}=\left(\tilde{a}_{B 1}, \tilde{a}_{B 2}, \ldots, \tilde{a}_{B n}\right)
$$

That $\tilde{a}_{B j}$ shows the priority of criterion $\mathrm{B}$ to the $\mathrm{j}$ criterion and it is obvious that $\tilde{a}_{B B}=$ $(1,1,1)$.

4) In the fourth step, the priority of all criteria is set to the weakest important criterion with a number 1 to 9 and is shown as follows:

$\tilde{A}_{w}=\left(\tilde{a}_{1 W}, \tilde{a}_{2 W}, \ldots, \tilde{a}_{n W}\right)$ 
That $\tilde{a}_{j W}$ represents the criterion priority $\mathrm{j}$ versus weakest important criterion of $\mathrm{W}$, and it is clear that $\tilde{a}_{W W}=(1,1,1)$.

5) Optimal weights are found at this step. $\left(\widetilde{w}_{1}^{*}, \widetilde{w}_{2}^{*}, \ldots, \widetilde{w}_{n}^{*}\right)$

The optimal values for the criteria are unique, which will have weights of $\widetilde{W}_{j} / \widetilde{W}_{B}$ and $\widetilde{W}_{W} /$ $\widetilde{W}_{j}$ for each pair:

$$
\frac{\widetilde{w}_{B}}{\widetilde{w}_{j}}=\tilde{a}_{B j}, \frac{\widetilde{w}_{j}}{\widetilde{w}_{W}}=\tilde{a}_{j W}
$$

To satisfy these conditions for all $\mathrm{j}$ 's, it need to find a solution that has the maximum value of the difference $\left|\frac{\widetilde{W}_{B}}{\widetilde{W}_{j}}-\tilde{a}_{B j}\right|$ and $\left|\frac{\widetilde{W}_{j}}{\widetilde{W}_{W}}-\tilde{a}_{j W}\right|$ be minimize. Given that the weights are nonnegative and are additive, the following problem can be solved (it should be noted $\widetilde{W}_{B}, \widetilde{W}_{j}, \widetilde{W}_{W}$, in F-BWM, there are triangular fuzzy membership numbers that are very different from non-fuzzy BWMs)

$\operatorname{Min} \max _{j}\left\{\left|\frac{\widetilde{W}_{B}}{\widetilde{W}_{j}}-\widetilde{a}_{B j}\right|,\left|\frac{\widetilde{W}_{j}}{\widetilde{W}_{W}}-\tilde{a}_{j W}\right|\right\}$

$\sum_{j=1}^{\substack{\text { s.t. } \\ n}} R\left(\widetilde{W}_{j}\right)=1$

$I_{j}^{w} \leq m_{j}^{w} \leq u_{j}^{w}$

$I_{j}^{W} \geq 0$

$\mathrm{j}=1,2, \ldots, \mathrm{n}$

that $\quad \widetilde{W}_{B}=\left(I_{B}^{W}, m_{B}^{W}, u_{B}^{W}\right), \widetilde{W}_{j}=\left(I_{j}^{W}, m_{j}^{W}, u_{j}^{W}\right), \widetilde{W}_{W}=\left(I_{W}^{W}, m_{W}^{W}, u_{W}^{W},\right)$

and $\left(I_{B j}, m_{B j}, u_{B j}\right), \tilde{a}_{j W}=\left(I_{j W}, m_{j W}, u_{j W}\right)=\tilde{a}_{B j}$

Step 5) can be expressed as follows:

$\min \tilde{\varepsilon}$

s.t.

$\left|\frac{\widetilde{W}_{\mathrm{B}}}{\widetilde{W}_{\mathrm{j}}}-\tilde{a}_{\mathrm{Bj}}\right| \leq \tilde{\varepsilon}$, for all $\mathrm{j}$

$\left|\frac{\widetilde{W}_{\mathrm{j}}}{\widetilde{W}_{\mathrm{W}}}-\tilde{a}_{\mathrm{jW}}\right| \leq \tilde{\varepsilon}$, for all $\mathrm{j}$

$\sum_{j=1}^{n} R\left(\widetilde{W}_{j}\right)=1$

$I_{j}^{w} \leq m_{j}^{w} \leq u_{j}^{w}$

$I_{j}^{W} \geq 0$

$\mathrm{j}=1,2, . ., \mathrm{n}$

that $\tilde{\varepsilon}=\left(I^{\varepsilon}, m^{\varepsilon}, u^{\varepsilon}\right)$

The fuzzy BWM Consistency Index is provided in Table 3. 
Table 3: F-BWM consistency index (Guo and Zhao, 2017)

\begin{tabular}{cccccc}
\hline $\begin{array}{c}\text { Linguistic } \\
\text { terms }\end{array}$ & $\begin{array}{c}\text { Equally } \\
\text { importance(EI) }\end{array}$ & $\begin{array}{c}\text { Weakly } \\
\text { important(WI) }\end{array}$ & $\begin{array}{c}\text { Fairly } \\
\text { Important(FI) }\end{array}$ & $\begin{array}{c}\text { Very } \\
\text { important(VI) }\end{array}$ & $\begin{array}{c}\text { Absolutely } \\
\text { important(AI) }\end{array}$ \\
\hline$\tilde{a}_{B W}$ & $(1,1,1)$ & $(2 / 3 ، 1 \cdot 3 / 2)$ & $(3 / 2,2,5 / 2)$ & $(5 / 2,3,7 / 2)$ & $(\mathbf{7 / 2 , 4 , 9 / 2 )}$ \\
$\mathrm{CL}$ & $3 / 00$ & $3 / 80$ & $5 / 29$ & $6 / 69$ & $\mathbf{8 / 0 4}$ \\
\hline
\end{tabular}

Given that $I^{\varepsilon} \leq m^{\varepsilon} \leq u^{\varepsilon}$ it is suggested that $\tilde{\varepsilon}^{*}=\left(k^{*}, k^{*}, k^{*}\right), k^{*} \leq I^{\varepsilon}$, then the above equation can be written as follows::

$\operatorname{Min} \tilde{\varepsilon}^{*}$

s.t.

$\left|\frac{\left(I_{B}^{W}, m_{B}^{W}, u_{B}^{W}\right)}{\left(I_{j}^{W}, m_{j}^{W}, u_{j}^{W}\right)}-\left(I_{B j}, m_{B j}, u_{B j}\right)\right| \leq\left(k^{*}, k^{*}, k^{*}\right)$

$\left|\frac{\left(I_{j}^{W}, m_{j}^{W}, u_{j}^{W}\right)}{\left(I_{W}^{W}, m_{W}^{W}, u_{W}^{W}\right)}-\left(I_{j W}, m_{j W}, u_{j W}\right)\right| \leq\left(k^{*}, k^{*}, k^{*}\right)$

$\sum_{j=1}^{n} R\left(\widetilde{W}_{j}\right)=1$

$I_{j}^{w} \leq m_{j}^{w} \leq u_{j}^{w}$

$I_{j}^{W} \geq 0$

$\mathrm{j}=1,2, \ldots, \mathrm{n}$

By solving this equation, it obtains the optimal fuzzy weights $\left(\widetilde{W}_{1}^{*}, \widetilde{W}_{2}^{*}, \ldots, \widetilde{W}_{n}^{*}\right)$.

\section{Consistency Ratio Calculation:}

A comparison will be perfectly consistent when $\tilde{a}_{B j} \times \tilde{a}_{j W}=\tilde{a}_{B W}$ for all j's that $\tilde{a}_{B j}, \tilde{a}_{j W}$ and $\tilde{a}_{B W}$ represent the best performance for, respectively according to criterion $\mathrm{j}$ and performance of criterion $\mathrm{j}$ compared to the worst criterion and performance of the best criterion to the worst criterion. Although it may not be possible for some j's not to be fully consistent, this is due to the fact that the consistency ratio is introduced to indicate how consistency compares. To do this, they calculate the least amount of comparative consistency (Guo and Zhao, 2017).

\section{3-3 F-WASPAS method}

The WASPAS method is one of the many innovative decision-making methods and it is applicable to solve very sensitive optimization problems. This method was introduced by Zavadskas et al. (2012) which is a combination of two methods, namely Weighted Sum Model (WSM) and Weighted Product Model (WPM) (Pourtaheri et al., 2015). This method is more accurate than that in independent methods. The accuracy of these models is one of the parameters that can be considered in choosing a multi-criteria decision-making method. Certain researchers also suggest that the combination of two models can increase the accuracy of it. This model can have high efficiency in complex decision-making problems, as well as the results of this model have highly accurate (Zavadskas et al., 2012).

The WASPAS-F method was presented by Zavaldskas et al. (2015). This method, like that in the WASPAS method, offers a combination of two WSM and the WPM methods in a fuzzy environment. This method also requires the weight of the criteria which should be calculated by other methods such as Chang Fuzzy AHP method or improved FUZZY-AHP 
method, or the Fuzzy BWM and fuzzy SWARA method, and so on and will be available to this method (Zavadskas et al., 2015).

\section{Steps of Fuzzy WASPAS Method}

At first, the fuzzy decision matrix is formed.

$$
\tilde{x}=\left[\begin{array}{ccccc}
\tilde{x}_{11} & \cdots & \tilde{x}_{1 j} & \cdots & \tilde{x}_{1 n} \\
\vdots & \ddots & \vdots & \ddots & \vdots \\
\tilde{x}_{i 1} & \cdots & \tilde{x}_{i j} & \cdots & \tilde{x}_{i n} \\
\vdots & \ddots & \vdots & \ddots & \vdots \\
\tilde{x}_{m 1} & \cdots & \tilde{x}_{m j} & \cdots & \tilde{x}_{m n}
\end{array}\right] ; i=\overline{1, m}, j=\overline{1, n}
$$

Where $\tilde{x}_{i j}$ represents the value of the function of alternative $\mathrm{i}$ compared to the alternative $\mathrm{j}$, which is determined by experts. Then proceed as follows:

1) Normalizing the Fuzzy Decision Matrix: In this step, the fuzzy decision matrix must be normalized. Normalization occurs through the following two equations. If the criterion has a positive aspect, then the first equation is used and if the criterion has a negative aspect, then the second equation is used for normalization.

$$
=\left\{\begin{array}{ll}
\frac{\tilde{x}_{i j}}{\max _{i} \tilde{x}_{i j}} & \text { if } \max _{i} \tilde{x}_{i j} \text { is preferable, } \\
\frac{\min _{i} \tilde{x}_{i j}}{\tilde{x}_{i j}} & \text { if } \min _{i} \tilde{x}_{i j} \text { is preferable; }
\end{array} \quad i=\overline{1, m}, j=\overline{1, n} \cdot \tilde{\bar{x}}_{i j}\right.
$$

2) Calculating the fuzzy matrix q: The matrix $q$ is obtained from the criterion weight in the normal matrix. This is WSM matrix.

$\tilde{\hat{x}}_{q}=\left[\begin{array}{ccccc}\tilde{\hat{x}}_{11} & \ldots & \tilde{\hat{x}}_{1 j} & \ldots & \tilde{\hat{x}}_{1 n} \\ \vdots & \ddots & \vdots & \ddots & \vdots \\ \tilde{\hat{x}}_{i 1} & \ldots & \tilde{\hat{x}}_{i j} & \ldots & \tilde{\hat{x}}_{i n} \\ \vdots & \ddots & \vdots & \ddots & \vdots \\ \tilde{\hat{x}}_{m 1} & \ldots & \tilde{\hat{x}}_{m j} & \ldots & \tilde{\hat{x}}_{m n}\end{array}\right] ; \tilde{\hat{x}}_{i j}=\tilde{\tilde{x}}_{i j} \widetilde{w}_{j}, i=\overline{1, m}, j=\overline{1, n}$.

3) Calculating the fuzzy matrix p: The matrix p is obtained from the normal fuzzy matrix power to the fuzzy weights. This is the same as the WPM.

$; \tilde{\overline{\bar{x}}}_{i j}=\widetilde{\tilde{x}}_{i j} \widetilde{W}_{j}, i=\overline{1, m}, j=\overline{1, n} \tilde{\hat{X}}_{p}=\left[\begin{array}{ccccc}\tilde{\overline{\bar{x}}}_{11} & \ldots & \tilde{\overline{\bar{x}}}_{1 j} & \ldots & \tilde{\overline{\bar{x}}}_{1 n} \\ \vdots & \ddots & \vdots & \ddots & \vdots \\ \tilde{\overline{\bar{x}}}_{i 1} & \ldots & \tilde{\overline{\bar{x}}}_{i j} & \ldots & \tilde{\overline{\bar{x}}}_{i n} \\ \vdots & \ddots & \vdots & \ddots & \vdots \\ \tilde{\overline{\bar{x}}}_{m 1} & \ldots & \underline{\overline{\bar{x}}}_{m j} & \ldots & \tilde{\overline{\bar{x}}}_{m n}\end{array}\right]$

4) The values of the matrix q are summed together, and the values of the matrix $p$ are multiplied (for each alternative).

According to WSM for each alternative: 
$\tilde{Q}_{i}=\sum_{j=1}^{n} \tilde{\hat{x}}_{i j}, i=\overline{1, m}$,

And according to WPM for each alternative:

$\tilde{p}_{i}=\prod_{j=1}^{n} \tilde{\bar{x}}_{i j}, i=\overline{1, m}$

5) The resulting numbers become defuzzy (Defuzzification can be obtained from the mean of fuzzy numbers).

$Q_{i}=\frac{1}{3}\left(Q_{i \alpha}+Q_{i \beta}+Q_{i \gamma}\right)$.

$P_{i}=\frac{1}{3}\left(P_{i \alpha}+P_{i \beta}+P_{i \gamma}\right)$.

6) Calculating the value of each alternative: the k value of each alternative is computed, and the alternatives are ranked (Turskis et al., 2015)

$k_{i}=\lambda \sum_{j=1}^{m} Q_{i}+(1-\lambda) \sum_{j=1}^{m} p_{i} \lambda=0, \ldots, 1, \quad 0 \leq k_{i} \leq 1$

$\lambda=\frac{\sum_{i=1}^{m} p_{i}}{\sum_{i=1}^{m} Q_{i}+\sum_{i=1}^{m} p_{i}}$

\section{Data Analysis}

To start with analysis, first, the decision tree which included main criteria, sub-criteria as well as alternatives and represented in Figure 3. 


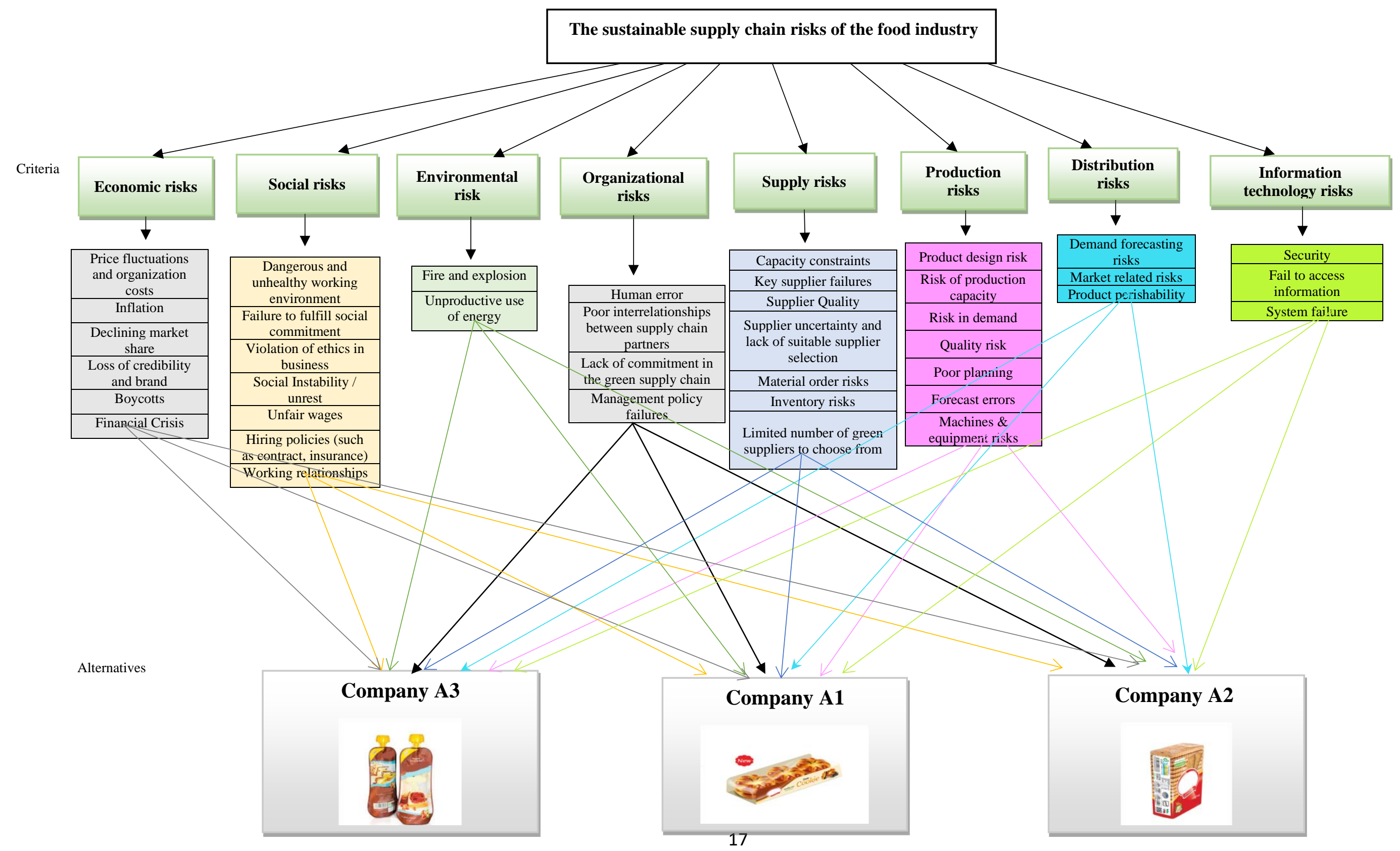

Figure 3. The network of sustainable supply chain managmeent risks in the food industry 


\section{4-1 Introduction of Research Factors}

This research consists of 39 criteria in eight dimensions, which are presented in Table 4.

Table 4. Introduction of research factors

\begin{tabular}{|c|c|c|c|}
\hline Dimensions & Describing each risk & Criterion & Code \\
\hline \multirow{6}{*}{$\begin{array}{l}\text { Economic risks } \\
\text { (C1) }\end{array}$} & \multirow{6}{*}{$\begin{array}{l}\text { The Economic dimension of } \\
\text { corporate monetary risks } \\
\text { generated by the financial } \\
\text { climate, the dishonest actions } \\
\text { of companies and } \\
\text { individuals, and the } \\
\text { commitment to sustained } \\
\text { economic growth(Giannakis } \\
\text { and Papadopoulos, 2016). }\end{array}$} & $\begin{array}{l}\text { Price fluctuations and } \\
\text { organization costs }\end{array}$ & $\mathrm{C} 11$ \\
\hline & & Inflation & $\mathrm{C} 12$ \\
\hline & & Declining market share & $\mathrm{C} 13$ \\
\hline & & Loss of credibility and brand & $\mathrm{C} 14$ \\
\hline & & Boycotts & $\mathrm{C} 15$ \\
\hline & & Financial crisis & C16 \\
\hline \multirow{7}{*}{$\begin{array}{l}\text { Social Risks } \\
\quad \text { (C2) }\end{array}$} & \multirow{7}{*}{$\begin{array}{l}\text { The social dimension relates } \\
\text { to the fulfillment of } \\
\text { commitments to workers, } \\
\text { clients, business partners, } \\
\text { governments and } \\
\text { communities (Giannakis and } \\
\text { Papadopoulos, 2016). }\end{array}$} & $\begin{array}{l}\text { Dangerous and unhealthy } \\
\text { working environment }\end{array}$ & $\mathrm{C} 21$ \\
\hline & & $\begin{array}{c}\text { Failure to fulfill social } \\
\text { commitment }\end{array}$ & $\mathrm{C} 22$ \\
\hline & & $\begin{array}{c}\text { Violation of ethics in } \\
\text { business }\end{array}$ & $\mathrm{C} 23$ \\
\hline & & Social Instability / unrest & $\mathrm{C} 24$ \\
\hline & & Unfair wages & $\mathrm{C} 25$ \\
\hline & & $\begin{array}{l}\text { Hiring policies (such as } \\
\text { contract, insurance) }\end{array}$ & $\mathrm{C} 26$ \\
\hline & & Working relationships & $\mathrm{C} 27$ \\
\hline \multirow[b]{2}{*}{$\begin{array}{l}\text { Environmental } \\
\text { risks }(\mathbf{C 3})\end{array}$} & \multirow{2}{*}{$\begin{array}{l}\text { Environmental risk can be } \\
\text { characterized as the } \\
\text { environmental damage } \\
\text { caused by daily activities in } \\
\text { the supply chain. (Mukhtar } e t \\
\text { al., 2019) }\end{array}$} & Fire and explosion & $\mathrm{C} 31$ \\
\hline & & Unproductive use of energy & $\mathrm{C} 32$ \\
\hline \multirow{4}{*}{$\begin{array}{l}\text { Organizational } \\
\text { Risks (C4) }\end{array}$} & \multirow{4}{*}{$\begin{array}{l}\text { Organizational Risks is an } \\
\text { evolving mechanism with a } \\
\text { systematic plan that covers } \\
\text { organizational ambiguity at } \\
\text { all levels (Rostamzadeh, } \\
\text { 2018). }\end{array}$} & Human error & $\mathrm{C} 41$ \\
\hline & & $\begin{array}{l}\text { Poor interrelationships } \\
\text { between supply chain } \\
\text { partners }\end{array}$ & $\mathrm{C} 42$ \\
\hline & & $\begin{array}{l}\text { Lack of commitment in the } \\
\text { green supply chain }\end{array}$ & $\mathrm{C} 43$ \\
\hline & & Management policy failures & $\mathrm{C} 44$ \\
\hline \multirow{7}{*}{$\begin{array}{l}\text { Supply Risks } \\
\text { (C5) }\end{array}$} & \multirow{7}{*}{$\begin{array}{l}\text { The risk of suppliers is one of } \\
\text { the key sources of risk in the } \\
\text { supply chain, an important } \\
\text { problem in today's dynamic } \\
\text { economic climate. }\end{array}$} & Capacity constraints & $\mathrm{C} 51$ \\
\hline & & Key supplier failures & C52 \\
\hline & & Supplier quality & $\mathrm{C} 53$ \\
\hline & & $\begin{array}{l}\text { Supplier uncertainty and lack } \\
\text { of suitable supplier selection }\end{array}$ & C54 \\
\hline & & Material order risks & $\mathrm{C} 55$ \\
\hline & & Inventory risks & C56 \\
\hline & & $\begin{array}{l}\text { Limited number of green } \\
\text { suppliers to choose from }\end{array}$ & C57 \\
\hline \multirow{5}{*}{$\begin{array}{l}\text { Production } \\
\text { Risks (C6) }\end{array}$} & \multirow{5}{*}{$\begin{array}{l}\text { Production Risks apply to the } \\
\text { risk that your yield or } \\
\text { performance levels would be } \\
\text { lower than expected. }\end{array}$} & Product design risk & C61 \\
\hline & & Risk of production capacity & C62 \\
\hline & & Risk of demand & C63 \\
\hline & & Quality risk & C64 \\
\hline & & Poor planning & C65 \\
\hline
\end{tabular}




\begin{tabular}{|c|c|c|c|}
\hline & & Forecast errors & C66 \\
\hline & & Machines \& equipment risks & C67 \\
\hline \multirow[b]{3}{*}{$\begin{array}{c}\text { Distribution } \\
\text { Risks (C7) }\end{array}$} & \multirow{3}{*}{$\begin{array}{l}\text { Manufacturing companies are } \\
\text { impacted by their own } \\
\text { distribution and supply } \\
\text { network because the } \\
\text { cooperation between the } \\
\text { companies and their suppliers } \\
\text { will reduce or increase the } \\
\text { costs of the business and the } \\
\text { sustainable companies' } \\
\text { smooth operations often rely } \\
\text { on their suppliers (Wasim } \\
\text { Syed } \text { et al., 2019). }\end{array}$} & Demand forecasting risks & C71 \\
\hline & & Market related risks & $\mathrm{C} 72$ \\
\hline & & Product perishability & C73 \\
\hline \multirow[b]{3}{*}{$\begin{array}{l}\text { Information } \\
\text { Technology } \\
\text { Risks (C8) }\end{array}$} & \multirow{3}{*}{$\begin{array}{l}\text { The Internet is becoming a } \\
\text { distribution platform for } \\
\text { companies dealing in digital- } \\
\text { only goods and information. } \\
\text { A host of digital security } \\
\text { challenges are created by } \\
\text { dependency on the Internet. } \\
\text { These problems vary from } \\
\text { protecting trade secrets to } \\
\text { securing information about } \\
\text { customers (Rostamzadeh et } \\
\text { al., 2018). }\end{array}$} & Security & $\mathrm{C} 81$ \\
\hline & & Fail to access information & $\mathrm{C} 72$ \\
\hline & & IT system failure & $\mathrm{C} 83$ \\
\hline
\end{tabular}

In the first step, the best and worst should be identified with the most important (best) and lowest important (worst) criterion. In this study, using the opinions of the experts of the research, the most important (best) and lowest important (worst) criteria were first identified in the main criteria, and then among the sub criteria of each criterion, which is presented in Table 5 .

Table 5. Best and Worst criteria

\begin{tabular}{|c|c|c|}
\hline Factor & Best criteria & Worst criteria \\
\hline Main criteria & Economic risks $(\mathrm{C} 1)$ & Information technology risks $(\mathrm{C} 8)$ \\
\hline Economic risks $(\mathrm{C} 1)$ & $\begin{array}{l}\text { Loss of credibility and brand } \\
\text { (C14) }\end{array}$ & Boycotts (C15) \\
\hline Social Risks (C2) & $\begin{array}{c}\text { Dangerous and unhealthy } \\
\text { working environment (C21) }\end{array}$ & Social Instability / unrest (C24) \\
\hline $\begin{array}{c}\text { Environmental risks } \\
\text { (C3) }\end{array}$ & $\begin{array}{l}\text { Unproductive use of energy } \\
\text { (C32) }\end{array}$ & Fire and explosion (C31) \\
\hline $\begin{array}{l}\text { Organizational Risks } \\
\text { (C4) }\end{array}$ & Human error $(\mathrm{C} 41)$ & $\begin{array}{l}\text { Poor interrelationships between supply } \\
\text { chain partners (C42) }\end{array}$ \\
\hline Supply risks (C5) & Supplier quality (C53) & $\begin{array}{l}\text { Limited number of green suppliers to } \\
\text { choose from (C57) }\end{array}$ \\
\hline Production Risks (C6) & Quality risk (C64) & Forecast errors (C66) \\
\hline $\begin{array}{l}\text { Distribution risks } \\
\text { (C7) }\end{array}$ & Product perishability (C73) & Demand forecasting risks (C71) \\
\hline $\begin{array}{c}\text { Information } \\
\text { technology risks (C8) }\end{array}$ & Security (C81) & IT system failure (C83) \\
\hline
\end{tabular}




\section{4-2 Paired Comparison Formation}

In this section, the paired comparison of best criteria to other criterion (BO) and also that other criteria are compared to the worst $(\mathrm{OW})$ criterion are carried out. In this study, firstly the paired comparison is formed and made available to nine experts in order to determine the degree of priority in paired comparisons. After obtaining all answers, paired comparisons were combined with the geometric mean method as following (Table 6). Moreover, other sub-criteria level comparisons are not mentioned but performed for this work.

Table 6. Paired comparison of the main criteria

\begin{tabular}{|c|c|c|c|c|c|c|c|c|}
\hline Best/worst criteia & C1 & $\mathrm{C} 2$ & $\mathrm{C3}$ & $\mathrm{C} 4$ & C5 & C6 & C7 & C8 \\
\hline Best criterion $\quad \mathrm{C} 1$ & $\begin{array}{l}\vec{\Xi} \\
=\end{array}$ & 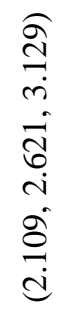 & $\begin{array}{l}\tilde{n} \\
m \\
m \\
\tilde{d}\end{array}$ & \begin{tabular}{l}
$\tilde{n}$ \\
$i$ \\
$i$ \\
\\
\hdashline
\end{tabular} & $\begin{array}{l}\tilde{n} \\
i \\
i \\
\tilde{a} \\
=\end{array}$ & $\begin{array}{l}\tilde{n} \\
\stackrel{-}{0} \\
\hat{b} \\
\stackrel{e}{0}\end{array}$ & $\begin{array}{l}\tilde{n} \\
i \\
i \\
\tilde{a} \\
=\end{array}$ & $\begin{array}{l}\tilde{n} \\
+ \\
\dot{v} \\
n \\
\tilde{d}\end{array}$ \\
\hline worst criterion $\quad \mathrm{C} 8$ & ' & 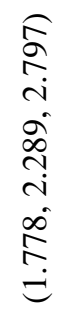 & $\begin{array}{l}\tilde{n} \\
\stackrel{-}{5} \\
\hat{b} \\
\stackrel{0}{0}\end{array}$ & 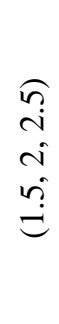 & $\begin{array}{l}\tilde{n} \\
i \\
i \\
\tilde{n} \\
\end{array}$ & $\begin{array}{l}\tilde{n} \\
\stackrel{-}{5} \\
\hat{b} \\
\stackrel{0}{0}\end{array}$ & $\begin{array}{l}\tilde{n} \\
i \\
i \\
\tilde{a} \\
\end{array}$ & 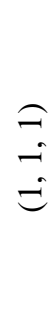 \\
\hline
\end{tabular}

\section{4-3 Calculating the weight of the criteria}

In this step, the relationship between two nonlinear optimization models were constructed. However, Guo and Zhao (2017) stated that in models with three or more criteria, it would be better to use a linearized version of the model. Therefore, the linear model of the F-BWM method was formed and it was solved by the LINGO 17 software and the weights of the criteria were obtained as follows in Table 7.

Table 7. Weight and Final Ranking of Main Criteria

\begin{tabular}{lccc}
\hline \multicolumn{1}{c}{ Criterion } & Fuzzy weight & $\begin{array}{c}\text { Definitive } \\
\text { weight }\end{array}$ & Ranking \\
\hline Economic risks $(\mathbf{C 1})$ & $(0.181,0.181,0.223)$ & 0.188 & 1 \\
\hline Social Risks (C2) & $(0.096,0.099,0.137)$ & 0.105 & 6 \\
\hline Environmental risks $(\mathbf{C} 3)$ & $(0.082,0.082,0.106)$ & 0.086 & 7 \\
\hline Organizational Risks $(\mathbf{C 4})$ & $(0.131,0.149,0.185)$ & 0.152 & 2 \\
\hline Supply risks $(\mathbf{C 5})$ & $(0.131,0.149,0.185)$ & 0.152 & 2 \\
\hline Production Risks $(\mathbf{C 6})$ & $(0.097,0.101,0.129)$ & 0.105 & 5 \\
\hline Distribution risks $(\mathbf{C} 7)$ & $(0.131,0.149,0.185)$ & 0.152 & 2 \\
\hline \multicolumn{1}{c}{ Information technology risks $(\mathbf{C} 8)$} & $(0.056,0.056,0.067)$ & 0.058 & 8 \\
\hline
\end{tabular}


In Table 7, the fuzzy weight is obtained directly by solving the model using the LINGO software. Furthermore, these fuzzy weights were converted to definitive weight by using equation $R\left(\tilde{a}_{i}\right)=\frac{l_{i}+4 m_{i}+u_{i}}{6}$.

For example, the fuzzy weight of economic risks is as follows $(0.0,0.181,0.223)$ that its definitive weight equal to $\frac{0.181+4 * 0.181+0.223}{6}=0.188$. Accordingly, the economic risk with the weight of 0.188 has obtained first rank and the IT risk with a weight of 0.058 has eighth rank.

Similarly, for sub-criteria, a linear optimization model is created and solved by the software that final weights are achieved.

4-4 Consistency Ratio

In this section, the consistency ratio of paired comparisons is computed. First, using the value of $\xi$ is extracted for each pair comparison which is the consistency ratio. Then, the optimal value of the objective function $(\xi *)$ of each linear model for paired comparison tables is divided by this amount of consistency index to achieve consistency ratio. The mathematical expression of the consistency ratio is: $\frac{\xi *}{\xi}$. If compatibility rate is closer to zero, indicating a more consistent paired comparison. This ratio is shown in Table 8.

Table 8. consistency ratio of paired comparison

\begin{tabular}{|c|c|c|c|}
\hline Factor & $\xi$ & $\tilde{\xi} *$ & Consistency Ratio \\
\hline Main criteria & 8.04 & 0.791 & 0.098 \\
\hline Economic risks (C1) & 8.04 & 0.216 & 0.027 \\
\hline Social Risks (C2) & 8.04 & 0.377 & 0.047 \\
\hline Environmental risks $(\mathrm{C} 3)$ & - & 0 & Always consistent \\
\hline Organizational risks $(\mathrm{C} 4)$ & 8.04 & 0.232 & 0.029 \\
\hline Supply risks (C5) & 8.04 & 0.456 & 0.057 \\
\hline Production Risks (C6) & 8.04 & 0.407 & 0.051 \\
\hline Distribution risks (C7) & 8.04 & 0.146 & 0.018 \\
\hline Information technology risks (C8) & 8.04 & 0.354 & 0.044 \\
\hline
\end{tabular}

\section{4-5 Final weights of sub-criteria}

The same procedure of criteria weight calculations is employed for sub-criteria as well. Fuzzy BWM was also used to calculate weight of sub-criteria. To calculate sub-criteria's weights, final weight of criteria was multiplied to relative weights of each sub-criteria. To compute sub-criteria weights, LINGO software was employed by developing a linear optimization model and solving the model to compute the final sub-criteria weights.

According to obtained result shown in Table 9, loss of credibility and brand, dangerous and unhealthy working environment, unproductive use of energy, human error, supplier quality, quality risk, product perishability, security are ranked at high and top ranked sub-criteria amongst others and need more attention in order to manage the sustainable supply chain risk. 
Table 9. Final weights of sub-criteria

\begin{tabular}{|c|c|c|c|c|}
\hline Dimensions & Criterion & Code & $\begin{array}{l}\text { Relative } \\
\text { weight }\end{array}$ & $\begin{array}{c}\text { Sub- } \\
\text { criteria } \\
\text { final } \\
\text { weight }\end{array}$ \\
\hline \multirow{6}{*}{$\begin{array}{l}\text { Economic } \\
\text { risks }(\mathrm{C} 1)\end{array}$} & Price fluctuations and organization costs & $\mathrm{C} 11$ & 0.185 & 0.0348 \\
\hline & Inflation & $\mathrm{C} 12$ & 0.106 & 0.0199 \\
\hline & Declining market share & $\mathrm{C} 13$ & 0.195 & 0.0367 \\
\hline & Loss of credibility and brand & $\mathrm{C} 14$ & 0.256 & 0.0481 \\
\hline & Boycotts & $\mathrm{C} 15$ & 0.061 & 0.0115 \\
\hline & Financial crisis & $\mathrm{C} 16$ & 0.195 & 0.0367 \\
\hline \multirow{7}{*}{$\begin{array}{l}\text { Social Risks } \\
\quad \text { (C2) }\end{array}$} & Dangerous and unhealthy working environment & $\mathrm{C} 21$ & 0.292 & 0.0307 \\
\hline & Failure to fulfill social commitment & $\mathrm{C} 22$ & 0.090 & 0.0095 \\
\hline & Violation of ethics in business & $\mathrm{C} 23$ & 0.152 & 0.016 \\
\hline & Social Instability / unrest & $\mathrm{C} 24$ & 0.067 & 0.007 \\
\hline & Unfair wages & $\mathrm{C} 25$ & 0.179 & 0.0188 \\
\hline & Hiring policies (such as contract, insurance) & $\mathrm{C} 26$ & 0.090 & 0.0095 \\
\hline & Working relationships & $\mathrm{C} 27$ & 0.129 & 0.0135 \\
\hline \multirow{2}{*}{$\begin{array}{l}\text { Environment } \\
\text { al risks }(\mathbf{C} 3)\end{array}$} & Fire and explosion & $\mathrm{C} 31$ & 0.202 & 0.0174 \\
\hline & Unproductive use of energy & $\mathrm{C} 32$ & 0.798 & 0.0686 \\
\hline \multirow{4}{*}{$\begin{array}{l}\text { Organization } \\
\text { al Risks (C4) }\end{array}$} & Human error & $\mathrm{C} 41$ & 0.420 & 0.0638 \\
\hline & $\begin{array}{l}\text { Poor interrelationships between supply chain } \\
\text { partners }\end{array}$ & $\mathrm{C} 42$ & 0.099 & 0.015 \\
\hline & Lack of commitment in the green supply chain & C43 & 0.204 & 0.031 \\
\hline & Management policy failures & $\mathrm{C} 44$ & 0.275 & 0.0418 \\
\hline \multirow{7}{*}{$\begin{array}{l}\text { Supply Risks } \\
\text { (C5) }\end{array}$} & Capacity constraints & C51 & 0.103 & 0.0157 \\
\hline & Key supplier failures & C52 & 0.122 & 0.0185 \\
\hline & Supplier quality & $\mathrm{C} 53$ & 0.260 & 0.0395 \\
\hline & $\begin{array}{l}\text { Supplier uncertainty and lack of suitable supplier } \\
\text { selection }\end{array}$ & C54 & 0.174 & 0.0264 \\
\hline & Material order risks & C55 & 0.174 & 0.0264 \\
\hline & Inventory risks & C56 & 0.103 & 0.0157 \\
\hline & Limited number of green suppliers to choose from & C57 & 0.063 & 0.0096 \\
\hline \multirow{7}{*}{$\begin{array}{l}\text { Production } \\
\text { Risks (C6) }\end{array}$} & Product design risk & C61 & 0.184 & 0.0193 \\
\hline & Risk of production capacity & C62 & 0.093 & 0.0098 \\
\hline & Risk of demand & C63 & 0.055 & 0.0163 \\
\hline & Quality risk & C64 & 0.178 & 0.0253 \\
\hline & Poor planning & C65 & 0.093 & 0.0098 \\
\hline & Forecast errors & C66 & 0.055 & 0.0058 \\
\hline & Machines \& equipment risks & C67 & 0.178 & 0.0187 \\
\hline \multirow{3}{*}{$\begin{array}{l}\text { Distribution } \\
\text { Risks (C7) }\end{array}$} & Demand forecasting risks & C71 & 0.138 & 0.021 \\
\hline & Market related risks & $\mathrm{C} 72$ & 0.294 & 0.0447 \\
\hline & Product perishability & $\mathrm{C} 73$ & 0.566 & 0.086 \\
\hline \multirow{3}{*}{$\begin{array}{l}\text { Information } \\
\text { Technology } \\
\text { Risks (C8) }\end{array}$} & Security & $\mathrm{C} 81$ & 0.539 & 0.0313 \\
\hline & Fail to access information & $\mathrm{C} 72$ & 0.333 & 0.0193 \\
\hline & IT system failure & $\mathrm{C} 83$ & 0.126 & 0.0073 \\
\hline
\end{tabular}




\section{4-6 Fuzzy WASPAS Method}

The F-WASPAS technique was first presented in 2015 by Turskis et al. (2015). This method is almost the same as the WASPAS method but is implemented in a fuzzy environment. Also, in this study, Linguistic scale and fuzzy numbers were as given in Table 10.

Table 10. Linguistic scale and corresponding fuzzy numbers for ranking alternatives (Patil and Kant, 2014)

\begin{tabular}{ccccc}
\hline \multirow{2}{*}{ Code } & \multirow{2}{*}{ Priorities } & \multicolumn{4}{c}{ Fuzzy Phase of priorities } \\
\cline { 3 - 5 } & & Lower limit (L) & Medium limit (m) & Upper limit (u) \\
\hline $\mathbf{1}$ & Very Poor & 1 & 1 & 3 \\
\hline $\mathbf{2}$ & Poor & 1 & 3 & 5 \\
\hline $\mathbf{3}$ & Medium & 3 & 5 & 7 \\
\hline $\mathbf{4}$ & Good & 5 & 7 & 9 \\
\hline $\mathbf{5}$ & Very Good & 7 & 9 & 11 \\
\hline
\end{tabular}

In the first step, the matrix of the decision is made up of this technique. The matrix of the decision was completed by experts.

In the second step, the matrix of the decision is normalized based on equations 3 and 4 . All sub criteria of research are to be positive.

In step 3, using equations 5 and 6, WSM (Q) and WPM (P) are calculated, and finally they are defuzzied via equations 7 and 8 (Table 11).

Table 11. WSM and WPM values

\begin{tabular}{ccccc}
\hline Alternatives & $\mathbf{Q}$ & $\mathbf{P}$ & DEFINITIVE Q & Definitive P \\
\hline A1 & $(0.52,0.71,0.9)$ & $(0.50,0.70,0.90)$ & 0.709 & 0.697 \\
\hline A2 & $(0.54,0.73,0.93)$ & $(0.53,0.73,0.92)$ & 0.734 & 0.724 \\
\hline A3 & $(0.55,0.74,0.94)$ & $(0.54,0.74,0.93)$ & 0.743 & 0.738
\end{tabular}

In the next step, the score of each company $(\mathrm{K})$ is calculated by the equation 15 , and the rank of the companies is based on it. According to Table 12, A3 ranked as first alternative, A2 as second alternative, and $\mathrm{A} 1$ as third alternative.

Table 12. Values for each supplier and their ranking

\begin{tabular}{cccc}
\hline Alternatives & K & normalized k & Rank \\
\hline (A1) & 0.703 & 0.323 & 3 \\
\hline (A2) & 0.729 & 0.336 & 2 \\
\hline (A3) & 0.740 & 0.341 & 1 \\
\hline
\end{tabular}

Figure 4 also represents the ranking of alternatives accordingly. 


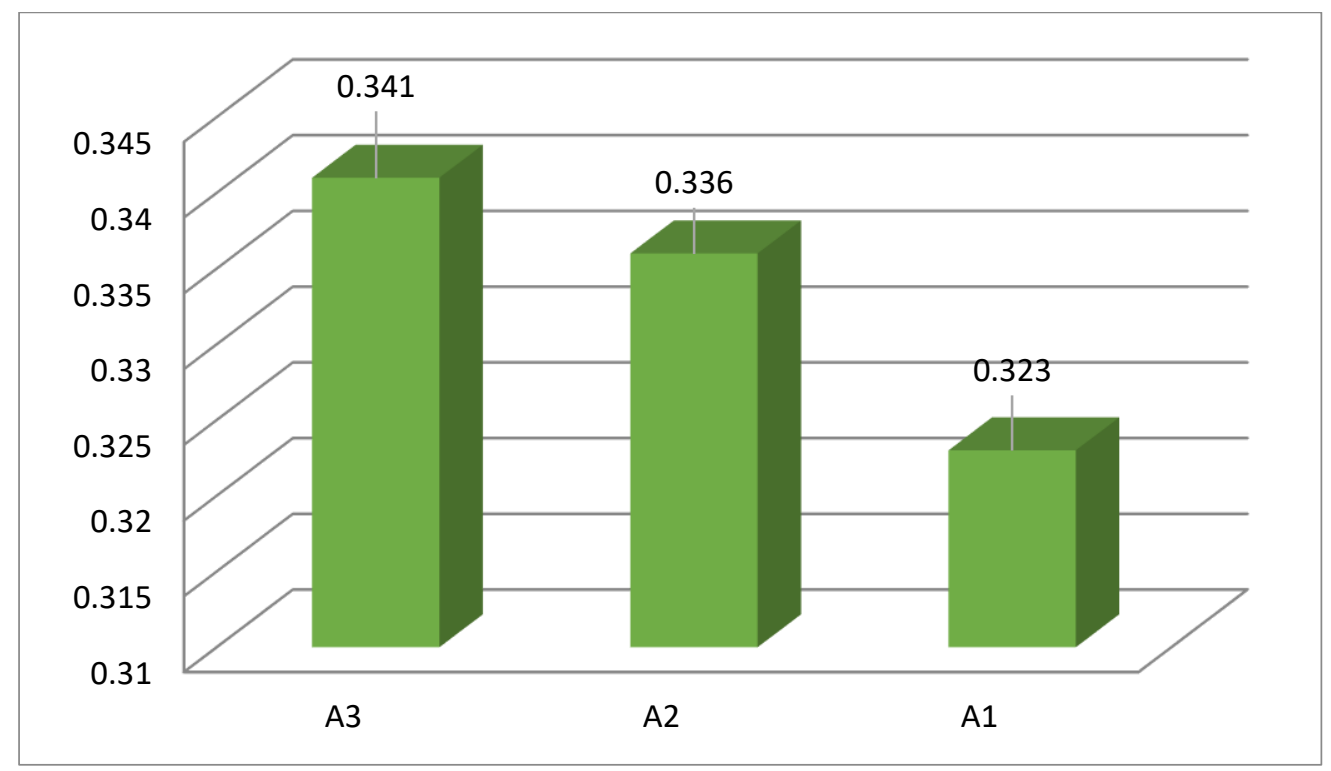

Figure 4. Weight chart and final ranking of companies

\section{Conclusion}

Although growing research has explored the nature of the supply chain and provided broader insights, little research has addressed the risks involved in the concept of sustainability across the supply chain. This work provided insight into sustainable supply chain development. The objective of this study was to assess the sustainable supply chain risk management in three food processing plants, which has been evaluated based on F-BWM and F-WASPAS multi-criteria decision-making methods. The proposed method, compared to other similar methods, has the ability to assess the accuracy of experts' opinions about the weight indicators given during the method process. In order to achieve the goal of the research, first various articles and researches that were done in this field were examined and the dimensions and components of risks related to sustainability were extracted. The research consists of eight main and 39 sub-criteria. First, the main and sub-criteria were weighted through F-BWM. After a pair comparison was made by nine experts, and after solving FBWM in LINGO, the following results were confirmed:

Among the main criteria, economic risk, supply risk, organizational risk, distribution risk, production risk, social risk, the environmental and IT risk ranked highest. Nevertheless, supply risk, organizational risk, and distribution risk were all equally ranked at second. In the economic dimension, the loss of credibility and brand, the financial crisis, declining market share, price fluctuations and organization costs, inflation and boycott achieved priority 1 to 6 , respectively. Furthermore, the financial crisis and decline in the market share ranked equally at the second. In the social dimension, dangerous and unhealthy working environment, unfair wages, violation of ethics in business, working relationships, failure to fulfill social commitment, hiring policies (such as contract, insurance policies) and social instability/unrest ranked $1^{\text {st }}$ to $7^{\text {th }}$, respectively. Also, the failure to fulfill social commitment and hiring policies (such as contract, insurance policies) were equally ranked at the $5^{\text {th }}$. In the environmental dimension, unproductive use of energy and fire and explosion ranked the first and second, respectively. In the organizational dimension, human error, management policy failures, lack of commitment in supply chain, poor interrelationships between supply chain partners ranked first to fourth. In dimension of supply, supplier quality, supplier 
uncertainty/ lack of suitable supplier selection, material order risks, key supplier failures, capacity constraints, inventory risks, and limited number of green suppliers to choose from obtained rank of 1 to 7 , respectively. Also, supplier uncertainty/lack of suitable supplier selection and material-order risks stood at the second rank and that they are of the same level of influence. The capacity constraints and inventory risks ranked equally at the fifth level. In the production dimension, quality risk, product design risk, machines and equipment risks, demand risk, poor planning, risk of production capacity, and forecast errors were ranked first to seventh, respectively. Also, poor planning and risk of production capacity got the fifth rank and that they are all of the same level of influence. In distribution dimension, product perishability, market related risks, and demand-forecasting risks were ranked first to third and in the latter dimension, ie, information technology, respectively, security, fail to access information and IT system failure ranked first to third. Finally, the consistency of paired comparison is considered by calculating the inconsistency ratio. Because their ratio approaches zero.

After gaining the weight of the main and sub-criteria, three alternatives (A1), (A2) and (A3) were identified and evaluated and ranked in terms of risk management. According to the results of F-WASPAS method, A3 ranked first, A2 second and A1 third. This framework was developed to identify and analyze the risks of sustainable supply chains in the food industry (e.g., confectionery and chocolate). Ghasemi et al. (2015) investigated indicators related to the sustainability of food supply chain and only these indicators were identified and prioritized, and their research has also been in the field of agriculture (citrus). The indicators were prioritized using the network analysis and the number of experts was 10 people. Rostamzadeh et al. (2018) assessed sustainable supply chain risk management using the TOPSIS-CRITIC method in fuzzy environments. As well as their study done on four petrochemical complexes. They examined seven criteria and 44 sub-criteria and used three decision makers. The results of this work reveal that sustainable production/manufacturer risks, sustainable supply risks, sustainable distribution risks were ranked as first, second and third criteria.

\section{The Implications of the Research}

Today one of the most important issues in supply chain management would be the risk management and sustainability. Social, environmental, economic, organizational, supply, distribution, production and information technology issues are elements of sustainability and attempts have been made to connect the sustainability and risk management of the supply chain. Research in the realm of food industry (confectionery and chocolate) for risk management is at its infancy. Since the main consumers are children, more attention must be paid to the quality of the products, as a result, raw material suppliers will have a significant role. Within the organization, all risks should be identified and controlled to ensure food safety and its environmental impact. Finally, by identifying and controlling all the risks mentioned under the economic dimension and in all other dimensions, for that matter, it is possible to provide a product of both quality and economic value to consumers, which will give the brand credibility for the organization. Consumers will safely put the products in his/her basket of goods with a peace of mind. In order to continue the work of food production units, along with progress and development, all aspects of supply chain management development should be consistent and that they should be prepared to respond to presence potential risks. Thus, this study suggests that supply chain managers consider incorporating the supply chain in order to establish a shared mechanism for risk reduction across the supplier-customer relationship.

Given that economic risk has received the highest rating, therefore it is suggested that have the right planning to deal with inflation. Companies should control costs and price 
fluctuations and identify their competitors and try not to lose their market share. At organizational risk, managers can increase partnerships and increase knowledge through collaborative collaboration, training programs. At the risk of sustainable supply, the selection of suppliers must be done carefully enough to provide raw materials in a timely manner and with appropriate quality. Regarding the risk of sustainable distribution, it is recommended to pay attention to the proximity of airports and the quality of roads and to forecast the amount of demand. In sustainable production risk, proper product design and production capacity must be planned and mistakes must be anticipated. To reduce social risk, it is recommended that managers control behaviors that violate business ethics, such as corruption, unfair business, and invasion of privacy, in order to achieve better performance in sustainable supply chain management. About environmental risk is recommended that organizations must prevent fraudulent and unethical activities for smooth and long-run companies. All environmental regulations made by governments and other regulatory bodies should be implemented. Also, in order to reduce environmental pollution and reduce its destructive effects to a reasonable extent, modern technologies in the studied industry can be suggested while maintaining the health, growth and survival of living organisms. At information technology, companies must ensure that accurate and timely data from all manufacturers reaches them and that they have adequate security.

This research was gained towards evaluating the risk management in three food industry units using the above-mentioned methods. According to the results obtained, one can conclude that; as the society grows and changes are made with the advancements in the units of production, the number of risks will become more and more diversified. Thus, risks should be reviewed once all the risk factors are identified and classified. Furthermore, in future studies, a combination of two other models to rank should be adopted. For example, F-BWM and F-WASPAS can be used and results can be compared in terms of their corresponding accuracies. Also, for each expert in BWM, future researches can run the model and obtain weights because the best and worst criteria are different for each of them. To explore the generalizability of this research, future research can use sensitivity analysis. Other industries can be employed as case studies. Since suppliers are important components of the supply chain and that they have a significant impact on the organization, the risk management of the sustainable supply chain should be always assessed and ultimately ranked as decision making tool. This work was used CVR procedure for categorization criteria and reducing attributes; thus, future study can use the fuzzy Delphi method for their tasks.

\section{References}

Afgan, N.H. and Carvalho, M.G. (2004), "Sustainability assessment of hydrogen energy system", Int.J. hydrogen energy, Vol. 29 No. 13, pp.1327-1342.

Ahi, P. and Searcy, C. (2013), “A comparative literature analysis of definitions for green and sustainable supply chain management”, Journal of Cleaner Production, Vol. 52, pp. 329-341.

Alam Tabriz, A., Modaresi, M. and Arab, A. (2017), "Analysis and Analysis of Stable Supply Chain Management Risks Based on the FSWARA Method", Second International Industrial Management Conference, Babolsar, Mazandaran university, Iran.

Aqlan, F. and Lam, S. (2015), “A fuzzy-based integrated framework for supply chain risk assessment”, International Journal of Production Economics, Vol. 161, pp. 54-63.

Badri Ahmadi, H., Kusi-Sarpong, S. and Rezaei, J. (2017), “Assessing the social sustainability of supply chains using best worst method. Resources”, Conservation and Recycling, Vol. 126, pp. 99-106. 
Bastas, A. and Liyanage, K. (2019), "Integrated quality and supply chain management business diagnostics for organizational sustainability improvement”. Sustainable Production and consumption, Vol. 17, pp. 11-30.

Bogataj, D., Hudoklin, D., Bogataj, M., Dimovski, V. and Colnar, S. (2020), "Risk Mitigation in a Meat Supply Chain with Options of Redirection", sustainability, Vol. 12, pp. 1-23.

Cervantes-Cabrera, O.A., and Briano-Turrent, G.D. (2018), "The importance of Risk Management Assessment: A proposal of an Index for Listed Companies", Journal of Accounting Research, Organization and Economics, Vol. 1 No. 2, pp. 122-137

Chen, Y.J. and Seshadri, S. (2006), "Supply chain structure and demand risk", Automatic, Vol. 42 No. 8, pp. 1291-1299.

Christopher, M. and Lee, H. (2004), “Mitigating supply chain risk through improved confidence, International Journal of Physical Distribution and Logistics Management, Vol. 34, pp. 388-396.

Darestani, S. A and Hojjat Shamami, N. (2019), "Performance evaluation of lean production based on balanced score card method using ANP and SIR: a case from Iranian home appliance industry". OPSEARCH, Vol. 56, pp. 717-738.

Dong, Q. and Cooper, O. (2016), “An orders-of-magnitude AHP supply chain risk assessment framework", International Journal of Production Economics., Vol. 182, pp. 144-15.

Ellis, S.C., Shockley, J. and Henry, R.M. (2011), "Making Sense of Supply Disruption Risk Research: A Conceptual Framework Grounded in Enactment Theory", Journal of Supply Chain Management, Vol. 47, pp. 65-96.

Fan, H., Li, G., Sun, H. and Cheng, TT. C. E. (2016), “An information processing perspective on supply chain risk management: antecedents, mechanism, and consequences, International Journal of Production Economics, Vol. 185, pp. 63-75.

Fritz, M. M. C. (2019), "Sustainable Supply Chain Management", In W. Leal Filho et al. (eds.) (Ed.), Responsible Consumption and Production, Encyclopedia of the UN Sustainable Development Goals, pp. 1-14.

Ghadge, A., Dahi, S. and Kalawsky, R. (2012), "Supply Chain Risk Management: present and future scope. International Journal of Logistics Management, Vol. 23 No. 3, pp. 313-339.

Ghadge, A., Jena, S.K., Kamble, S., Misra, D. and Tiwari, M.K. (2020), "Impact of financial risk on supply chains: a manufacturer-supplier relational perspective", International Journal of Production Research, DOI: 10.1080/00207543.2020.1834638.

Ghadimi, P., Wang, C. and Klim, M. (2019), "Sustainable supply chain modeling and analysis: past debate, present problem and future challenges". Resources, Conservation and Recycling, Vol. 140, pp. 72-84.

Giannakis, M. and Papadopoulos, T. (2016), "Supply chain sustainability: A risk management approach". International Journal of Production Economics, Vol. 171, pp. 455-470.

Gokarn, S. and Kuthambalayan, T. (2019), “Creating sustainable fresh produce supply chains by managing uncertainties”. Journal of Cleaner Production, Vol. 207, pp. 908-919.

Gold, S., Hahn, R. and Seuring, S. (2013), "Sustainable supply chain management in base of the pyramid" food projects-a path to triple bottom line approaches for multinationals". International Business Review, Vol. 22, pp. 784-799.

Gouda, S. and Saranga, H. (2018), "Sustainable supply chains for supply chain sustainability: impact of sustainability efforts on supply chain risk", International Journal of Production Research, Vol. 56 No. 1, pp. 1-16.

Gualandris, J. and Kalchschmidt, M. (2014), "Customer pressure and innovativeness: their role in sustainable supply chain management”. Journal of Purchasing and Supply Management, Vol. 20, pp. 92-103.

Guo, S. and Zhao, H., (2017). "Fuzzy best-worst multi-criteria decision-making method and its applications". Knowledge-Based Systems, Vol. 121, pp. 23-31. 
Jayaram, J., Tan, K-Ch. and Subramanian, N. (2010), "Examining the interrelationships between supply chain integration scope and supply chain management efforts", International Journal of Production Research, Vol. 48 No. 22, pp. 6837- 6857.

Khan, M.N., Akhtar, P. and Merali, Y. (2018), "Strategies and effective decision-making against terrorism affecting supply chain risk management and security: A novel combination of triangulated methods", Industrial Management \& Data Systems, Vol. 118 No. 7, pp. 1528-1546.

Ladisa, P. (2017), "Industrial Machines and Support Equipment: Criteria for Sustainable Production", Conference: World Engineering Forum 2017, Rome - Italy.

Lawshe, C. H. (1975), A quantitative approach to content validity. Pers. Psychol. 28, 563-575

Lee, E., Park, Y. and Gye Shin, J. (2009), "Large engineering project risk management using a Bayesian belief network”. Expert Systems with Applications, Vol. 36, pp. 5880-5887.

Li, G., Fan, H., Lee, P. K. and Cheng, T. (2015), "Joint supply chain risk management: An agency and collaboration perspective", International Journal of Production Economics, Vol. 164, pp. 83-94.

Mangla, S., Kumar, P. and Barua, M. (2015), "Risk analysis in green supply chain using fuzzy AHP approach (A case study)". Resources, Conservation and Recycling, Vol. 104, pp. 375-390.

Mhelembe, K. and Mafini, C. (2019), "Modelling the link between supply chain risk, flexibility and performance in the public sector", South African Journal of Economic and Management Sciences, Vol. 22 No. 1, pp. 1-12.

Mihalis, G. and Thanos P. (2016), "Supply chain sustainability: a risk management approach", Int. J. Production Economic, Vol. 171, pp. 455-470.

Mirzaei, S. and Darestani, S. A. (2016), "Development of failure mode and effects analysis using fuzzy analytical network process”. Int. J. Productivity and Quality Management. Vol. 17 No. 2, pp. 215-235.

Mirzaei, S., Moradi Tadi, A., Pirzadeh, N. and Darestani, S. A. (2014), "Development of Failure Modes and Effects Analysis using ANP and Fuzzy Saw”, Int. J. DAMA International. Vol. 3 No. 3, pp. 425-432.

Muhammad Rafi-Ul-Shan, P., B. Grant, D., Perry, P. and Ahmed, S. (2018), "Relationship between sustainability and risk management in fashion supply chains (a systematic literature review)". International Journal of Retail and Distribution Management, Vol. 46, pp. 466-486.

Mukhtar, A., Romli, A., Abdullateef, M. and Al-Bashiri, H. (2019), "Environmental Risks in Supply Chain: Recommendations and Directions for Future Research", Joint Conference on Green Engineering Technology \& Applied Computing.

Munir, M., Jajja, M. Sh. S. (2020), “Kamran Ali Chatha, Sami Farooq, Supply Chain Risk Management and Operational Performance: The Enabling Role of Supply Chain Integration", International Journal of Production Economics, https://doi.org/10.1016/j.ijpe.2020.107667

Nikookar Noshabadi, M. (2014), "Investigating the Proposal for a Risk Management Project in Telecommunication Companies". International Management Conference, Mobin Cultural Ambassadors Institute, Tehran.

Ortegoli, A. and Kabaranzad Ghadim, M.R. (2016), "The effect of risk factors on the green supply chain and prioritizing of the effects by using AHP”, International Journal of Humanities and Cultural Studies (IJHCS), pp. 1478-1493.

Ossadnik, W., Schinke, S. and Kaspar, R.H. (2016), “Group Aggregation Techniques for Analytic Hierarchy Process and Analytic Network Process: A Comparative Analysis”, Group Decision and Negotiation, Vol. 25, pp. $421-457$.

Ouedraogo, I, Girard, A., Vanclooster, M. and Jonard, F. (2020), "Modelling the Temporal Dynamics of Groundwater Pollution Risks at the African Scale”, Water, Vol. 12 No. 5, pp. 1-16.

Palousis, N., Luong, L. and Abhary, K. (2010), "Sustainability risk identification in product development", International Journal of Sustainable Engineering, Vol. 3 No. 2, pp. 70-80. 
Patil, S.K. and Kant, R. (2014), “A fuzzy AHP-TOPSIS framework for ranking the solutions of Knowledge Management adoption in Supply Chain to overcome its barriers". Expert Systems with Applications, Vol. 41, pp. 679-693.

Paul, S., Essam, D. and Sarker, R. (2016), "Managing risk and disruption in production-inventory and supply chain systems: A review”, Journal of Industrial and Management Optimization, Vol. 12 No. 3, pp. 1009-1029.

Pourtaheri, M., Fatahi, A., Nemati, R. and Adineh Vand, A. (2015), "Explaining the Advantages of Using the WASPAS Decision Making Combined Model for Locating Tourist Destinations in Villages (Case Study: Tourist Villages of Lorestan Province)". Space planning, Vol. 2 No. 20, pp. 113-137.

Qorri, A., Mujkic, Z. and Kraslawski, A. (2018), “A conceptual framework for measuring sustainability performance of supply chains”. Journal of Cleaner Production, Vol. 189, pp. 570-584.

Raayat Pisheh, M.A., Ghasemi, A.R., Hadadi, A. and Raayat Pisheh, S. (2015), "Identification and Prioritization of Indicators Involved in Sustainability in the Food Supply Chain", Journal of Environmental Science and Technology, Vol. 19 No. 4, pp. 369-382.

Rajesh, R. and Ravi, V. (2015), "Modeling enablers of supply chain risk mitigation in electronic supply chains: A Greye DEMATEL approach”, Compute. Ind. Eng, Vol. 87, pp. 126-139.

Rezaei, J. (2015), “Best-worst multi-criteria decision-making method”. Omega, Vol. 53, pp. 49-57.

Rostamzadeh, R., Keshavarz Ghorabaee, M., Govindan, K., Esmaeili, A. and Bodaghi Khajeh Nobar, H. (2018), "Evaluation of sustainable supply chain risk management using an integrated fuzzy TOPSIS-critic approach", Journal of Cleaner Production, Vol. 175, pp. 651-669.

Sarabi, E.P. and Darestani, S.A. (2020), "Developing a decision support system for logistics service provider selection employing fuzzy MULTIMOORA \& BWM in mining equipment manufacturing", Applied Soft Computing Journal, 106849, https://doi.org/10.1016/j.asoc.2020.106849.

Schult, J. and Hallstedt, S.I. (2018), Company Risk Management in Light of the Sustainability Transition, Sustainability 2018, Vol. 10 No. 11, pp. 1-25.

Seuring, S. (2013), "A review of modeling approaches for sustainable supply chain management". Decision Support Systems, Vol. 54, pp. 1513-1520.

Seuring, S. and Muller, M. (2008), "From a literature review to a conceptual framework for sustainable supply chain management”. Journal of Cleaner Production, Vol. 16, pp. 1699-1710.

Seyedan, M. and Mofakheri, F. (2020), "Predictive big data analytics for supply chain demand forecasting: methods, applications, and research opportunities", Journal of Big Data, Vol. 7, 53.

Shafiq, A., Klassen, R.D., Awaysheh, A. and Johnson, F. (2017), "Exploring the implications of supply risk on sustainability performance", International Journal of Operations \& Production Management, Vol. 37 No. 3, pp. 1-39.

Sodhi, M.T. and Tang, Ch. (2009), "Managing supply chain disruptions via time-based risk management", Managing Supply Chain Risk and Vulnerability, pp. 29-40.

Song, W., Ming, X. and Liu, H. (2017), "Identifying critical risk factors of sustainable supply chain management: a rough strength-relation analysis method", Journal of Cleaner Production, Vol. 143, pp. 100115 .

Sreedevi, R. and Saranga, H. (2017), "Uncertainty and supply chain risk: the moderating role of supply chain flexibility in risk mitigation”. International Journal of Production Economics, Vol. 193, pp. 332-342.

Su, C., Horng, D. and Chen, H. (2016), "Improving sustainable supply chain management using a novel hierarchical grey-Dematel approach”, Journal of Cleaner Production, Vol. 134, pp. 469-481.

Sun, Y., Bi, K. and Yin, Sh. (2020), "Measuring and Integrating Risk Management into Green Innovation Practices for Green Manufacturing under the Global Value Chain”, Sustainability, Vol. 12 No. 2, pp: 1-33. 
Tse, Y. K., Zhang, M., Tan, K. H., Pawar, K. and Fernandes, K. (2019), "Managing quality risk in supply chain to drive firm's performance: The roles of control mechanisms", Journal of Business Research, Vol. 97, pp. 291-303.

Tummala, R. and Schoenherr, T. (2011), "Assessing and managing risks using the supply chain risk management process SCRMP”, Supply Chain Manage Int.J. Vol. 16 No. 6, 474-483.

Turskis, Z., Zavadskas, E.K., Antucheviciene, J. and Kosareva, N. (2015), “A hybrid model based on fuzzy AHP and fuzzy WASPAS for construction site selection", International Journal of Computers Communications \& Control, Vol. 10, pp. 113-128.

Valinejad, F. and Rahmani, D. (2018), "Sustainability risk management in the supply chain of telecommunication companies (a case study)", Journal of Cleaner Production, Vol. 203, pp. 53-67.

Vazifehdan, M.N. and Darestani, S.A. (2019), “Green logistics outsourcing employing multi decision making and quality function development in the petrochemical industry", The Asian Journal of Shipping and Logistics, Vol. 35 No. 4, pp. 243-254.

Wan Ahmad, W., Rezaei, J., Sadaghiani, S. and Tavasszy, A. L. (2017), "Evaluation of the external forces affecting the sustainability of oil and gas supply chain using best worst method". Journal of Cleaner Production, Vol. 153, pp. 242-252.

Wasim Syed, Muzzammil., Li, J.Z., Junaid, M., Ye, X. and Ziaullah, M. (2019), “An Empirical Examination of Sustainable Supply Chain Risk and Integration Practices: A Performance-Based Evidence from Pakistan", Sustainability, Vol. 11 No. 19, pp. 1-21.

Wenyan, S., Xinguo, M. and Hu-Chen, L. (2017), "Identifying critical risk factors of sustainable supply chain management: a rough strength-relation analysis method", Journal of Cleaner Production, Vol. 143, pp. 100115.

Wiengarten, F., Humphreys, P., Gimenez, C. and Mclvor, R. (2016), "Risk, risk management practices, and the success of supply chain integration". International Journal of Production Economics, Vol. 171, pp. 361370 .

$\mathrm{Wu}$, Z. and Pagell, M. (2011), "Balancing priorities: decision-making in sustainable supply chain management”. Journal of Operations Management, Vol. 29, pp. 577-590.

Yakovleva, N., Sarkis, J. and Sloan, T. (2010), "Sustainability indicators for the food supply chain". Environmental Assessment and Management in the Food Industry, pp. 297-329.

Zavadskas, E.K., Turskis, Z. and Antucheviciene, J. (2015), "Selecting a Contractor by Using a Novel Method for Multiple Attribute Analysis: Weighted Aggregated Sum Product Assessment with Grey Values (WASPASG)", Studies in Informatics and Control, Vol. 24 No. 2, pp. 141-150.

Zavadskas, E.K., Turskis, Z. and Antucheviciene, J., Zakarevicius, A. (2012), “Optimization of weighted aggregated sum product assessment”. Elektronika ir Elektrotechnika, Vol. 122, pp. 3-6. 